WHC-EP- -0363

DE91 000295

\title{
Solid Waste Management Program Plan
}

D. R. Duncan

Date Published

August 1990

Prepared for the U.S. Department of Energy

Office of Environmental Restoration and Waste Management

(2) Westinghouse $\begin{aligned} & \text { P.O. Box } 1970 \\ & \text { Hantord Company }\end{aligned}$

Hanford Operations and Engineering Contractor for the

U.S. Department of Energy under Contract DE-AC06-87RL10930 


\section{CONTENTS}

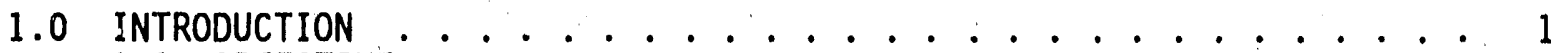

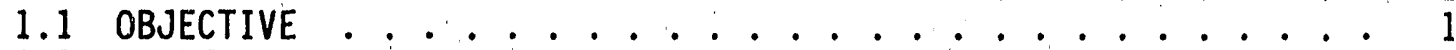

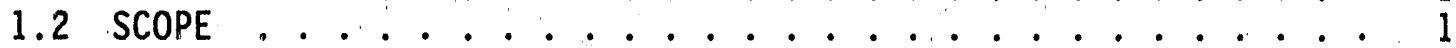

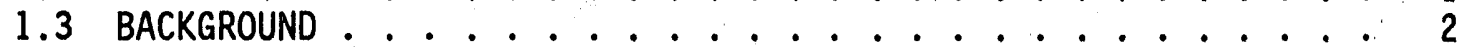

1.3.1 Historical .................. 2

1.3.2 Pre-1970 ................ 3

1.3.3 Transuranic Waste . . . . . . . . . . . . 3

1.3 .4 Low Level Waste. . . . . . . . . . . . . . . . . 4

1.3.5 Mixed Waste............... . . 4

1.3.6 Nonradioactive Hazardous and Toxic Waste ..... 5

1.4 DOCUMENT BASELINE .................... 5

2.0 SOLID WASTE MANAGEMENT ORGANIZATIONAL STRUCTURE ........ 7

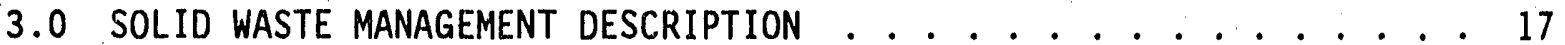

3.1 CURRENT ACTIVITIES . . . . . . . . . . . . . 17

3.2 SOLID WASTE MANAGEMENT STRATEGY . . . . . . . . . 20

3.3 SCHEDULE . . . . . . . . . . . . . 22

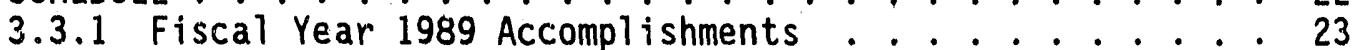

3.3.2 Expected Fiscal Year 1990 Accompl ishments...... 26

3.3.3 Expected Fiscal Year 1991 Accomplishments . . . . . . . 28

3.3.4 Forecast Outyear Accomplishments ......... 29

3.4 COST . . . . . . 30

3.4.1 Work Breakdown structure ......... 30

3.4.2 Work Breakdown Structure Implementation ........ 35

3.4 .3 Budgets .................. 35

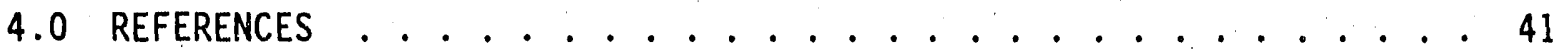

APPENDIXES:

A DOCUMENT BASELINE ................ A-1

B FACILITIES ....................... B-1 


\section{LIST OF FIGURES}

1 U.S. Department of Energy-Richland Operations Office Organization . : 8

2 Westinghouse Hanford Company Organization .. . . . . . . . . . g

3 Ervironmental and Waste Management Divisions Organization . . . . . 10

4 Waste Management Division Organization ............. 11

5 solid Waste Management Function Organization . . . . . . . . . 12

6 Solid Waste Overview Diagram ............... 18

7 Sol id Waste Management Summary Schedule . . . . . . . . . . . 24

8 Defense Haste Management Division Work Breakdown Structure . . . . . 31

9 Solid Waste Management Work Breakdown Structure . . . . . . . . . 32

\section{LIST OF TABLES}

1 Solid Waste Management (ML) Budget . . . . . . . . . . . 36

2 Solid Waste Management (W2) Budget . . . . . . . . . . . 37

3. Solid Waste Management (MS) Budget .............. 39

4 Summary Budget ................... 40 
Document Tit.le: SOLID WASTE MANAGEMENT PROGRAM PLAN

Prepared by:

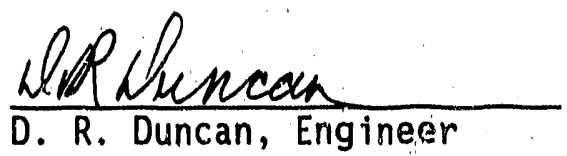

$\frac{8-28-90}{\text { Date }}$

Reviewed by:

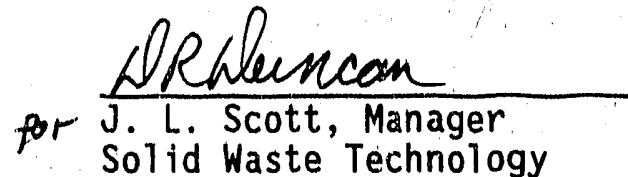

$8-28-48$

J. L. Scott, Manager
Solid Waste Technology

Date

Approved by:

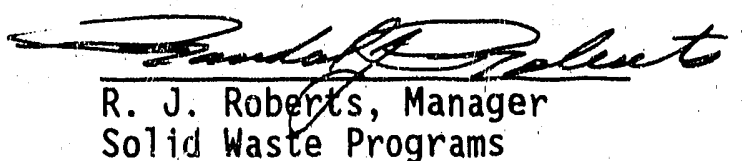

$\frac{8-28-90}{\text { Date }}$

Sol id Waste Programs 


\section{LIST OF TERMS}

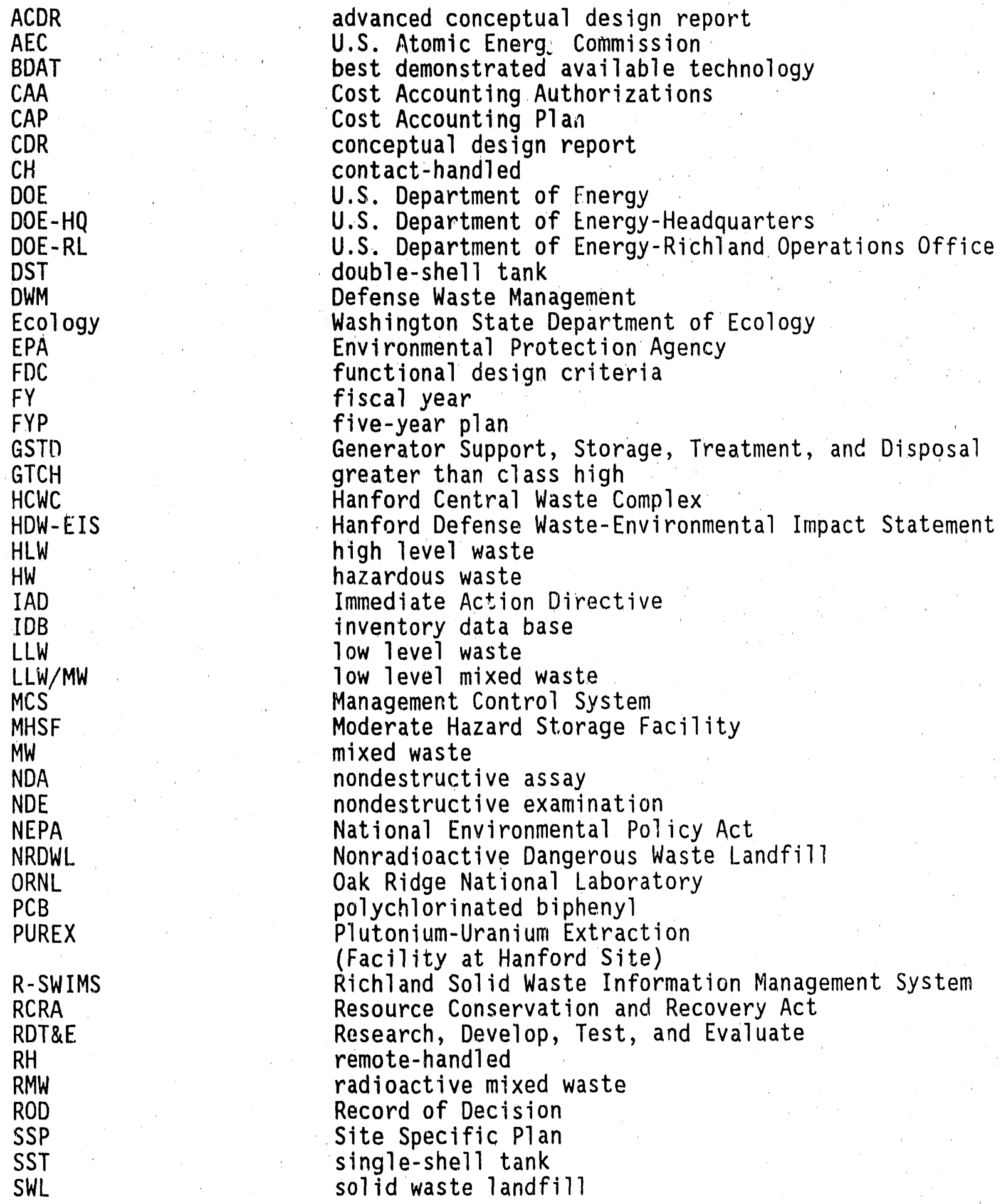




\section{LIST OF TERMS (continued)}

SWM

SWMPP

Tri-Party Agreement

TRU

TRU/MW

TRUSAF

TSCA

TSD

WAC

WBS

West inghouse Hanford

WIPP

WMD

WRAP
Solid Waste Management

Solid Waste Management Program Plan

Hanford Federal Facility Agreement and Consent Order transuranic

Transuranic Mixed Waste

Transuranic Storage and Assay Facility

Toxic Substances Control Act

treatment, storage, or disposal

Washington Administrative Code

work breakdown structure

Westinghouse Hanford Company

Waste Isolation Pilot Plant

Waste Management Division

Waste Receiving and Packaging 
WHC - EP -0363

\section{SOLID WASTE MANAGEMENT PROGRAM PLAN}

\subsection{INTRODUCTION}

\subsection{OBJECTIVE}

The objective of the Solid Waste Management Program Plan (SWMPP) is to nrovide a summary level comprehensive approach for the storage, treatment, and disposal of current and future solid waste received at the Hanford Site (from onsite and offsite generators) in a manner compliant with current and evolving regulations and orders (federal, state, and Westinghouse Hanford Company [Westinghouse Hanford]). The Plan also presents activities required for disposal of selected wastes currently in retrievable storage. The SWMPP provides a central focus for the description and control of cost, scope, and schedule of Hanford Site solid waste activities, and provides a vehicle for ready communication of the scope of those activities to onsite and offsite organizations. This Plan represents the most complete description available of Hanford Site Solid Waste Management (SWM) activities and the interfaces between those activities. It will be updated annually to reflect changes in plans due to evolving regulatory requirements and/or the SWM mission.

\subsection{SCOPE}

This Plan will focus on summarizing activities completed or expected to be completed in fiscal year (FY) 1989 and 1990 and forecast those to be completed in FY 1991 and outyears. A previous version of the SWMPP was drafted in 1988 and released as a letter report.

The scope of solid waste within the SWMPP will be any solid waste managed by the Westinghouse Hanford SWM function, within the Defense Waste Management (DWM) Division, which includes solid materials, containerized liquid or semisolid materials, and containerized gaseous materials contained in drums or boxes or other containers.

The following are the principal solid waste types within the scope of the plan:

Low Level Waste. Radioactive waste that is less than $100 \mathrm{nCi} / \mathrm{g}$ in activity of transuranic (TRU) constituents and is not classified as high level waste $(H L W)$, spent nuclear fuel, or TRU waste.

Transuranic Waste. Radioactive waste that contains alpha-emitting TRU radionuclides with half-1ives greater than 20-yr and activities greater than $100 \mathrm{nCi} / \mathrm{g}$; TRU radionuclides are those having an atomic number greater than 92. In addition to TRU radionuclides, radium sources and $233 \mathrm{U}$ in concentrations greater than $100 \mathrm{nCi} / \mathrm{g}$ of the waste matrix are designated TRU waste because of similar hazards. 
Mixed Waste. Radioactive waste that contains components that are dangerous as defined by the Washington Dangerous Waste Regulations, codified as Chapter 173-303 of the Washington Administrative Code (WAC), which implements for the State of Washington the hazardous waste (HW) regulations of the Resource Conservation and Recovery Act (RCRA). Mixed waste will be either low level waste (LLW) or TRU.

Nonradioactive Hazardous Waste. Waste whose only regulated components are those defined by the WAC 173-303.

A11 waste handled by SWM will be within one of the above types.

Waste management and environmental restoration activities have been divided by the Hanford Site Waste Management and Environmental Restoration Integration Plan (WHC-EP-0348) into seven missions. These missions encompass all actions supporting the top-level mission of the Environmental and Waste Management Divisions to safely store, treat, and dispose of radioactive and HW and remediate inactive sites and facilities at the Hanford Site: In addition to Solid Waste, the other missions are:

- Single-shel1 tanks (SST)

- Double-shell tanks (DST)

- Liquid effluents

- Encapsulated wastes (cesium, strontium capsules)

- Past Practice Units (Pre-1970 burial grourids, cribs, ponds, ditches, contaminated soil sites)

- Surplus facilities.

This Plan will focus on the Solid Waste mission. However, solid wastes generated by the above missions and included in solid waste forecasts and Storage/Disposal Approval Records will be handled by SWM as appropriate according to the practices and requirements discussed in this Plan.

\subsection{BACKGROUND}

\subsubsection{Historical}

Solid waste management has undergone an evolutionary process as the nation's environmental, deferse, and regulatory priorities and administrative framework have changed. This section is a brief description of the history of SWM practices, presented by waste type, in chronological order. 


\subsubsection{Pre-1970}

The defense materials production mission at the Hanford Site began in 1944, resulting in radioactive waste disposal on the Hanford Site. At that time there was no distinction separating L.LW and TRU waste. All solid radioactive waste was disposed of in shallow land trenches. The U.S. Atomic Energy Commission (AEC) directed (Immediate Action Directive 0511-21, March 20, 1970) that after Apri1 30, 1970, AEC sites segregate "waste with known or detectable contamination of transuranium nuclides" from other types of wastes. Such wastes were to be packaged and stored to be readily retrievabie as contamination-free packages within 20-yr. After 20-yr, retrievability was to continue to be possible. This policy was formulated in consideration of the long half-lives of TRU isotopes. The 20-yr interim storage period was stipulated to allow time to study the best disposal a) ternative.

The Immediate Action Directive (IAD) did not provide a detailed definition of TRU waste. Contractors to the AEC implemented the IAD as well as possible within limits of detection equipment.

\subsubsection{Transuranic Waste}

Segregated TRU wastes were placed in storage configurations specified by each site. The Hanford Site interim storage areas consisted of shallow 1 and trenches, concrete lined "V" trenches, earth-covered asphalt pads, and caissons.

Handling and shipping practices for TRU waste containers with high surface dose rates differed, due to the necessity of avoiding personnel exposure. Wastes that required shipment by shielded cask were placed in caissons, underground concrete or metal cylindrical structures. This practice occurred prior to 1970 and did not change after the 1970 IAD segregation linit. This resulted in a division into contact-handled (CH) and remotehandled $(\mathrm{RH})$ waste, with the separation occurring at a $200-\mathrm{mrem} / \mathrm{h}$ dose rate at the container surface.

The segregation limit for TRU waste was changed with the 1973 issuance of AEC manual 0511 (Radioactive Waste Management, September 19, 1973) to material contaminated with certain alpha-emitting radionuclides and activity greater than $10 \mathrm{nCi} / \mathrm{g}$. The radionuclides included were $233 \mathrm{U}$ plus its daughter products, plutonium, and transplutonium nuclides with the exception of $238 \mathrm{Pu}$ and $241 \mathrm{Pu}$.

In 1982, the TRU waste segregation limits were changed to $100 \mathrm{nCi} / \mathrm{g}$ by U.S. Department of Energy (DOE) Order 5820.1 (Management of Transuranic Material, September 30,1982 ). This caused no change in waste handling practices other than decreasing the relative volume of radioactive waste designated as TRU wast?. 
Storage practices for TRU waste were changed at the Hanford Site in FY 1985 in response to DOE Order 5820.2 (Radioactive Waste Management) in order to facilitate requirements for offsite shipment and geologic disposal at the Waste Isolation Pilot Plant (WIPP) Site. When certification to the WIPP waste acceptance criteria was approved in 1986, newly generated CH TRU drum waste began to be stored above ground at the Hanford site in the Transuranic Storage and Assay Facility (TRUSAF) in preparation for shipment to the WIPP Site. This practice will continue with the expected addition of new storage facilities for $\mathrm{CH}$ waste that cannot be handled in TRUSAF, due to space, floor-loading restriction, and lack of generator certification plans. This implements the Hanford Defense Waste-Environmental Impact Statement (HDW-EIS) Record of Decision (ROD) of April 8, 1988, to ship newly generated TRU waste, along with retrievably stored TRU waste, to WIPP. The TRU waste and associated contaminated soil volumes in pre-1970 burial grounds (termed buried waste) will require additional evaluation as stated in the ROD before decisions regarding disposal are made.

Currently, the Plutonium/Uranium Extraction (PUREX) and $Z$ Plant facilities are the only facilities at the Hanford Site that can ship certified waste to TRUSAF. Other Hanford Site facilities are in the process of being certified. The beginning date for shipment to WIPP from Hanford is uncertain; large scale shipments of $\mathrm{CH}$ TRU from Waste Receiving and Packaging (WRAP) Module I will begin in 1996 when Module I is operational, but earilier shipments are being explored.

Newly generated RH TRU waste will no longer be stored in underground caissons, but is to be stored as CH TRU in shielded drums. Remote-handled TRU waste will be shipped from the Hanford Site to the WIPP Site for disposal.

\subsubsection{Low Leve1 Waste}

There was no distinction separating TRU waste from LLW placed in the Hanford Site burial grounds until after April 30, 1970. Since then, the majority of Hanford Site solid waste classified as LLW has been disposed of in trenches or burial grounds. Prior to October 1979, some DOE LLW was shipped to commercial disposal sites. In the early 1980's, low-level liquid organic waste was barined from land disposal at the Hanford Site to avoid the potential danger from the chelating agent in the waste which would negate the ion exchange properties of the soil. In 1982, as a result of the ban, a decision was made to store the liquid organic material in the burial grounds in the same manner as the TRU waste; also, LLW Tiquid organics that had flashpoints greater than $150^{\circ} \mathrm{F}$ were to be stored on asphalt pads while those that had lower flashpoints were to be placed retrievably in earthen trenches. This practice continued until below-grade storage was terminated in 1988 .

\subsubsection{Mixed Waste}

On May 18, 1987, the DOE issued an interpretive rule under the Atomic Energy Act clarifying DOE obligations under the RCRA, which is promulgated in Washington State by the Washington State Dangerous Waste Regulations. As 
a result, al1 DOE radioactive waste contaminated with HW under RCRA (or at the Hanford Site, dangerous waste under the WAC) is termed radioactive mixed waste (RMW) and subject to regulation by the DOE and WAC. This created a category of mixed waste (MW) within the TRU and LLW waste classes that requires separate waste management disposition and segregation from other radioactive waste and other hazardous or dangerous material constituents.

In 1987, the Hanford Site elected to cease disposal of MW below $200 \mathrm{mrem} / \mathrm{h}$ in unlined trenches and to construct facilities for the proper storage of these wastes. In February 1988, a verbal agreement with the State stipulated that RMW with a dose equivalent less than $200 \mathrm{mr} \cdot \mathrm{m} / \mathrm{h}$ would be retrievably stored and placed into buildings (the Hanford Central Waste Cumplex [HCWC]) to meet all of the Washingtion State requirements. The waste greater than $200 \mathrm{mrem} / \mathrm{h}$ (drag-off waste) would be disposed of below ground so that the requirements of As Low as Reasonably Achievable would be met.

\subsubsection{Nonradioactive Hazardous and Toxic Waste}

The Central Landfill, including the Solid Waste Landfill (SWL) and the Nonradioactive Dangerous Waste Landfi11 (NRDWL), was opened in 1973. The SWL is operational and contains office, bulky, construction, and demolition waste of a nonradioactive and nonhazardous nature. Therefore regulation of treatment or disposal under the DOE regulations or RCRA is not required, although the provisions of WAC 173-304 for nonhazardous solid waste apply. The NRDWL had some trenches closed in 1982 and was completely closed in May 1985. Treatment and disposal of its wastes may be required but will depend on the closure plan to be prepared for the facility.

Nonradioactive HWs are regulated as dangerous wastes by the State under the WAC. Dangerous wastes are treated at several Hanford Site facilities. The bulk of these wastes are stored and shipped offsite for disposal, destruction, or recycling.

The principal waste regulated by the Toxic Substances Control Act (TSCA) on the Hanford Site is polychlorinated biphenyl (PCB), which is regulated by the Environmental Protection Agency (EPA) and TSCA pursuant to 40 CFR 761 . Storage of PCB waste is in approved facilities according to other constituents and is regulated solely by TSCA; if those constituents are also present, DOE and WAC regulations also apply. Pretreatment of PCB waste at the Hanford Site may be required depending on studies to be performed. Disposal is through licensed disposal contractors at offsite locations.

\subsection{DOCUMENT BASELINE}

There are many regulatory driving forces for SWM. These are presented in federal regulations and orders, Washington State regulations, and Westinghouse Hanford manuals and policies. These documents are summarized and shown in a hierarchical fashion in Appendix $A$. 
WHC-EP-0363

\subsection{SOLID WASTE MANAGEMENT ORGANIZATIONAL STRUCTURE}

Westinghouse Hanford activities are overseen by the U.S. Department of Energy-Richland Operations Office (DOE- $\mathrm{ZL}$ ). An organization chart of DOE-RL is given in Figure 1. The Waste Management Division (WMD) provides the direct budget, scope, and schedule guidance for solid waste efforts with in DOE-RL. With in the WMD, the Operations Branch has the largest responsibility for solid waste; the other branches of the Division, Vitrification/Program Integration and Technology Development, also have responsibility for oversight of areas such as waste minimization and technology plans and funding.

Solid waste activities at Westinghouse Hanford are managed by the SWM Function, within the WMD. The primary mission of SWM is to plan for, initiate and monitor design and construction of, and operate and maintain necessary processes and facilities to receive, store, treat, and dispose of solid LLW, TRU, low level mixed waste (LLW/MW), transuranic mixed waste (TRU/MW), and HW. The top-level Westinghouse Hanford organization chart is shown in Figures 2 and 3. The WMD structure is shown in Figure 4. An organization chart for the SWM Function is given in Figure 5 . The organizations reporting in line structure to SWM are shown with solid lines and the significant organizations interfacing in a matrix role are shown with dashed lines. The roles of the interfacing organizations are described below:

Onsite and Offsite Waste Generators. Waste generators are responsible for certifying and shipping waste to SWM facilities according to requirements of the annualiy revised WHC-EP-0063-1, Hanford Site Radioactive Sol id Waste Acceptance Criteria, or WHC-CM-5-16, Nonradioactive Dangerous Waste Packaging and Disposal Requilements (applicable only to onsite generators).

Environmental Division. The Environmental Division (see Figure 4) is responsible for scoping of National Environmental Policy Act (NEPA) documentation, RCRA permits, closure plans, Comprehensive Environmental Response, Compensation, and Liability Act plans, and other work in response to federal or state environmental regulations for al1 of Westinghouse Hanford. Typically, much of the actual information gathering and document preparation in response to environmental regulations will be performed by operating organizations, including. SWM. The Environmental Division also provides review of documents and activities to ensure conformance with regulations, is responsible for planning and support for performance assessments for solid waste disposal, and examines barrier development for final closure of disposal sites. The Division acts as the Westinghouse Hanford interface with the Washington State Department of Ecology (Ecology) and Region X of the EPA.

Environmental and Waste Program Integration. The sections within this department (see Figure 3 ) provide top-level planning for the WMD (as well as the Environmental Division) in the form of program plans and scope and milestone monitoring. Monitoring of the Hanford Federal Facility Agreement and Consent Order (Tri-Party Agreement) (Ecology et a1 1989) activities are centered within this department. Other responsibilities include monitoring and control of budgets and change control, as well as development and control of schedules. 
Figure 1. U.S. Department of Energy-Richland Operations Office Organization.

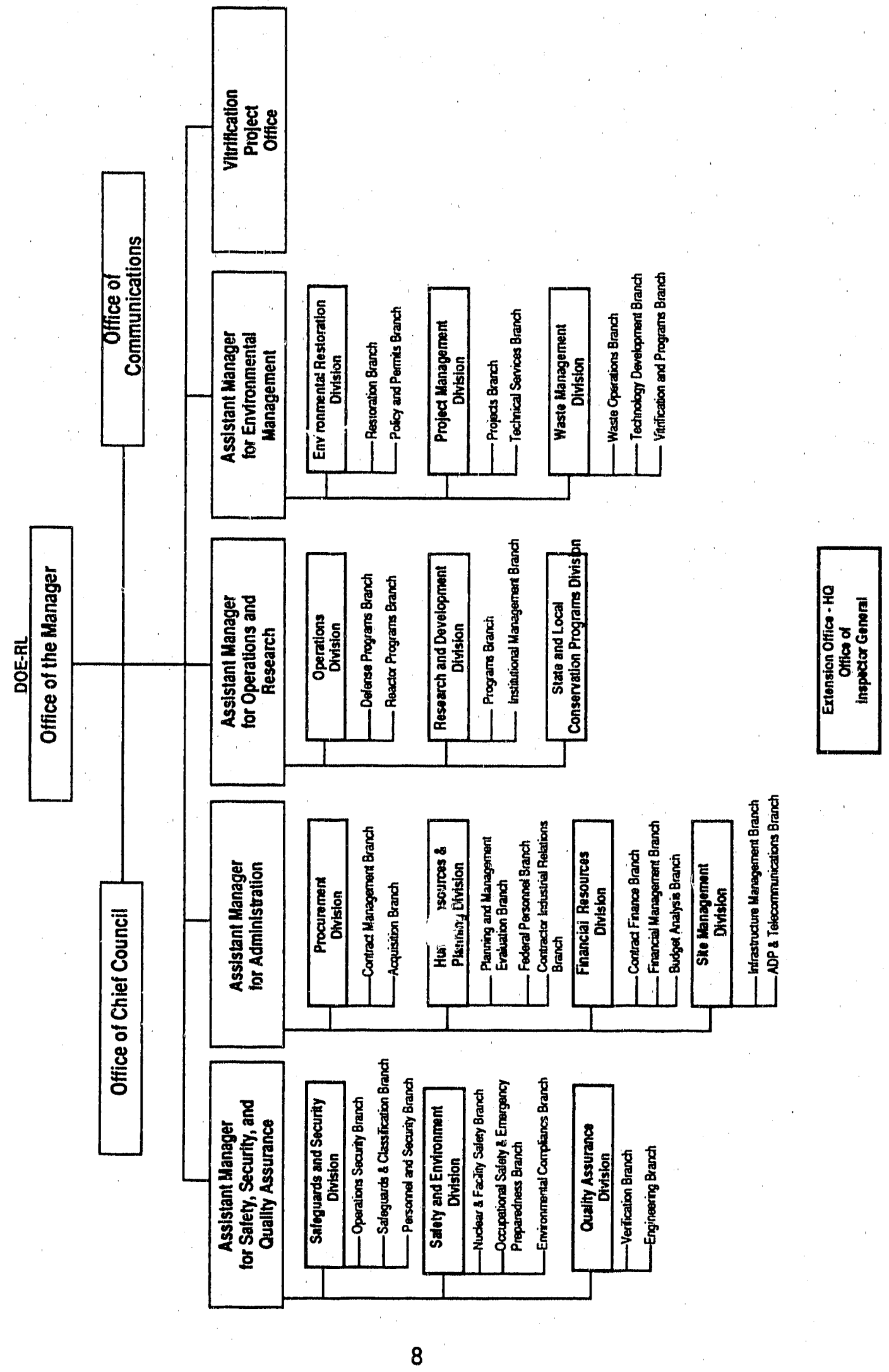


Figure 2. Westinghouse Hanford Company Organization.

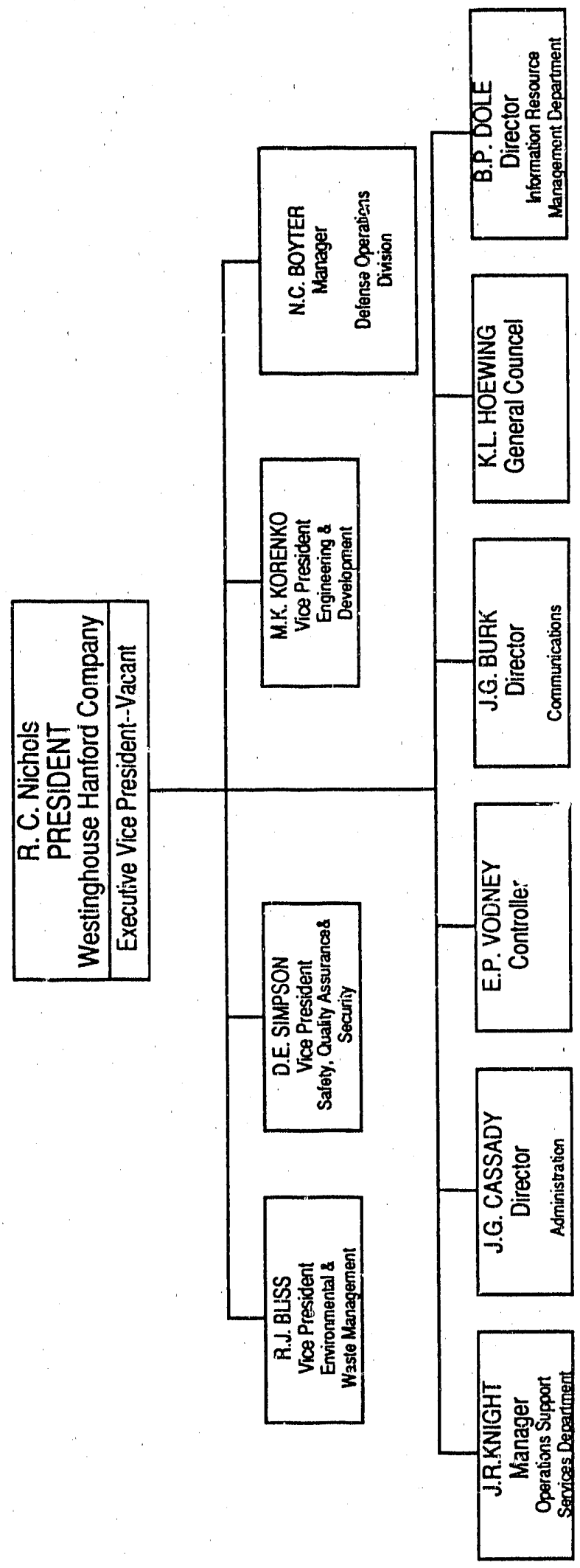


Figure 3. Environmental and Waste Management

Divisions Organization.

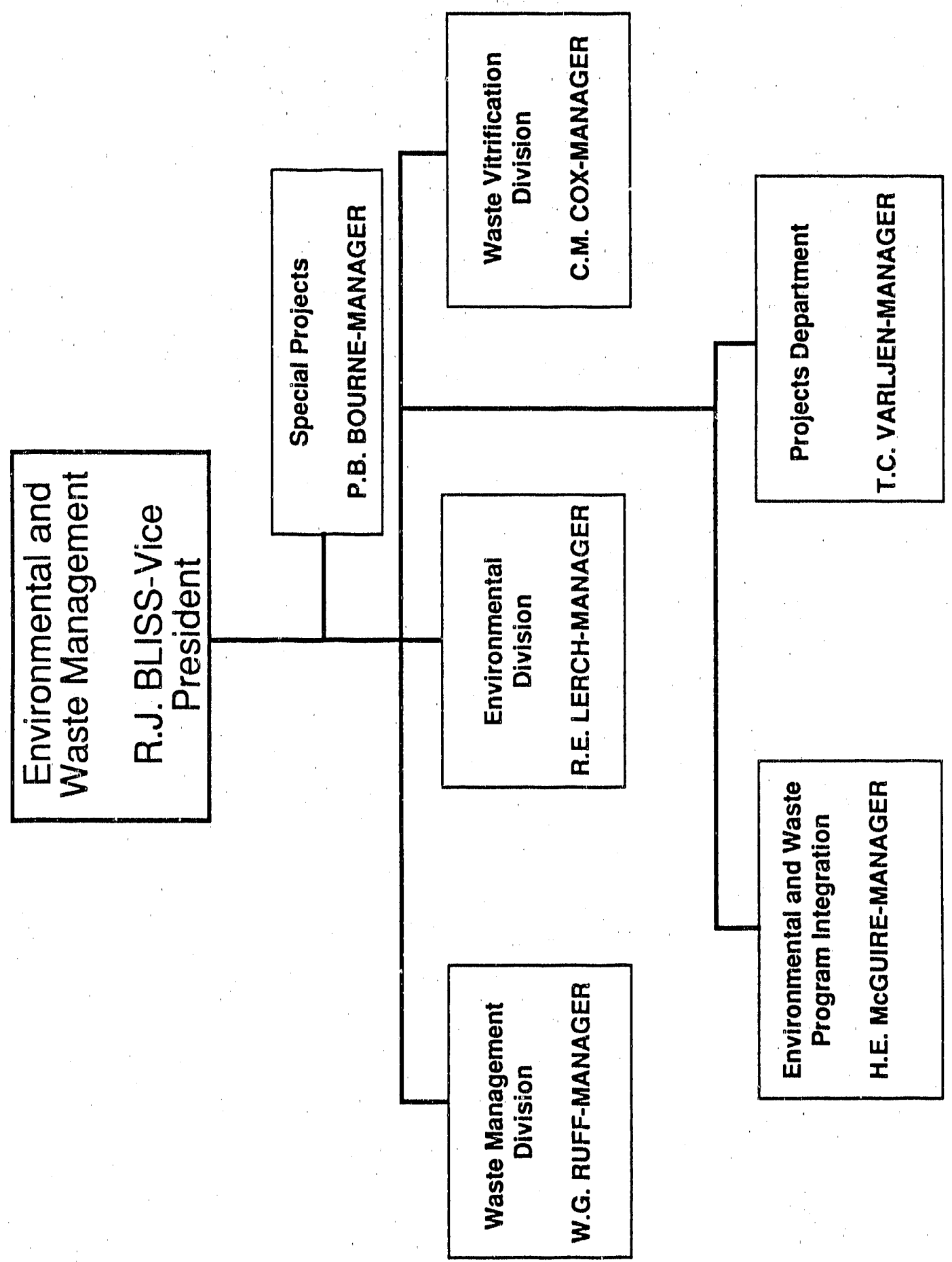


WHC-EP-0363

Fiqure 4. Waste Management Division Organization.

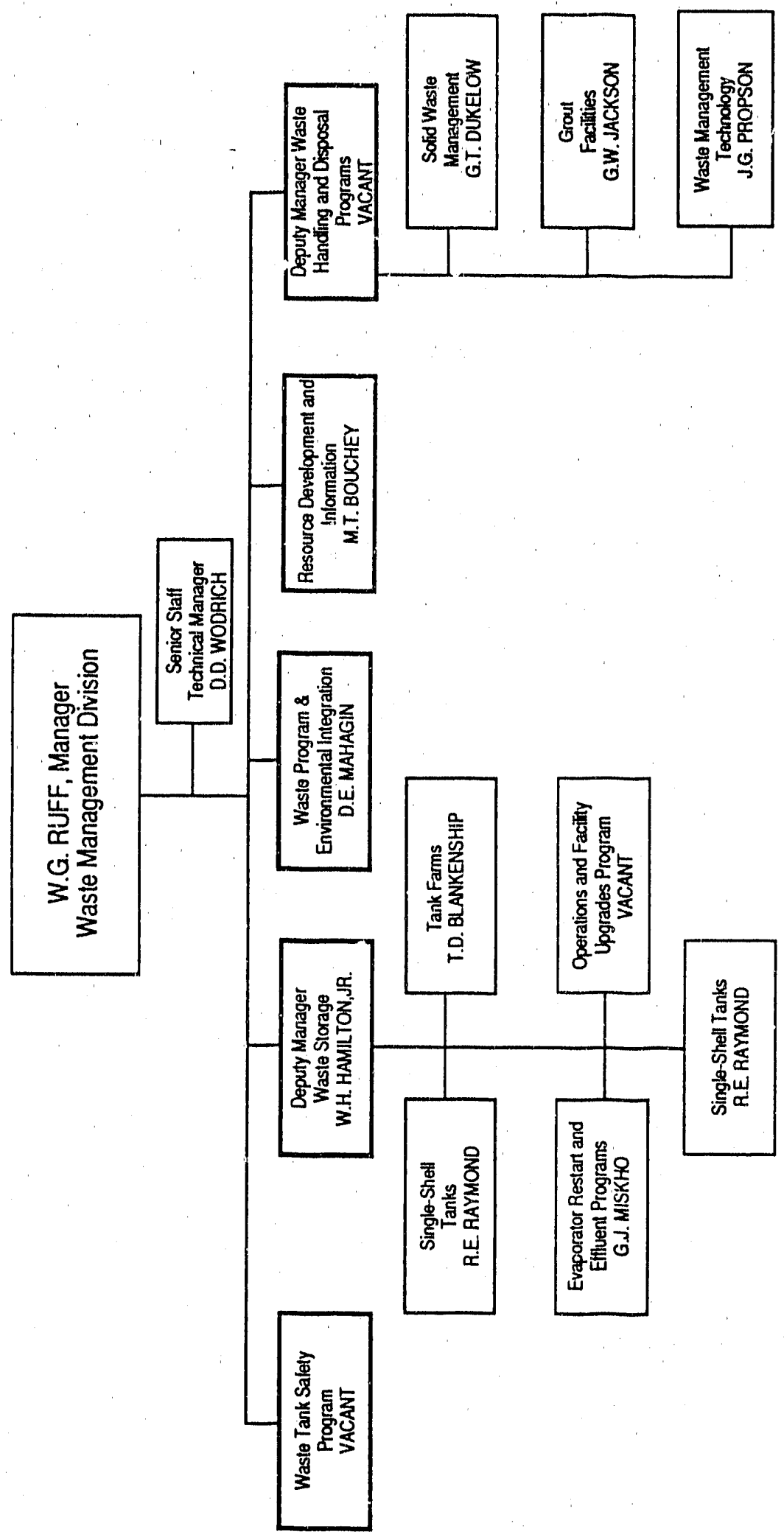


WHC-EP-0363

Figure 5. Solid Waste Management Function Organization.

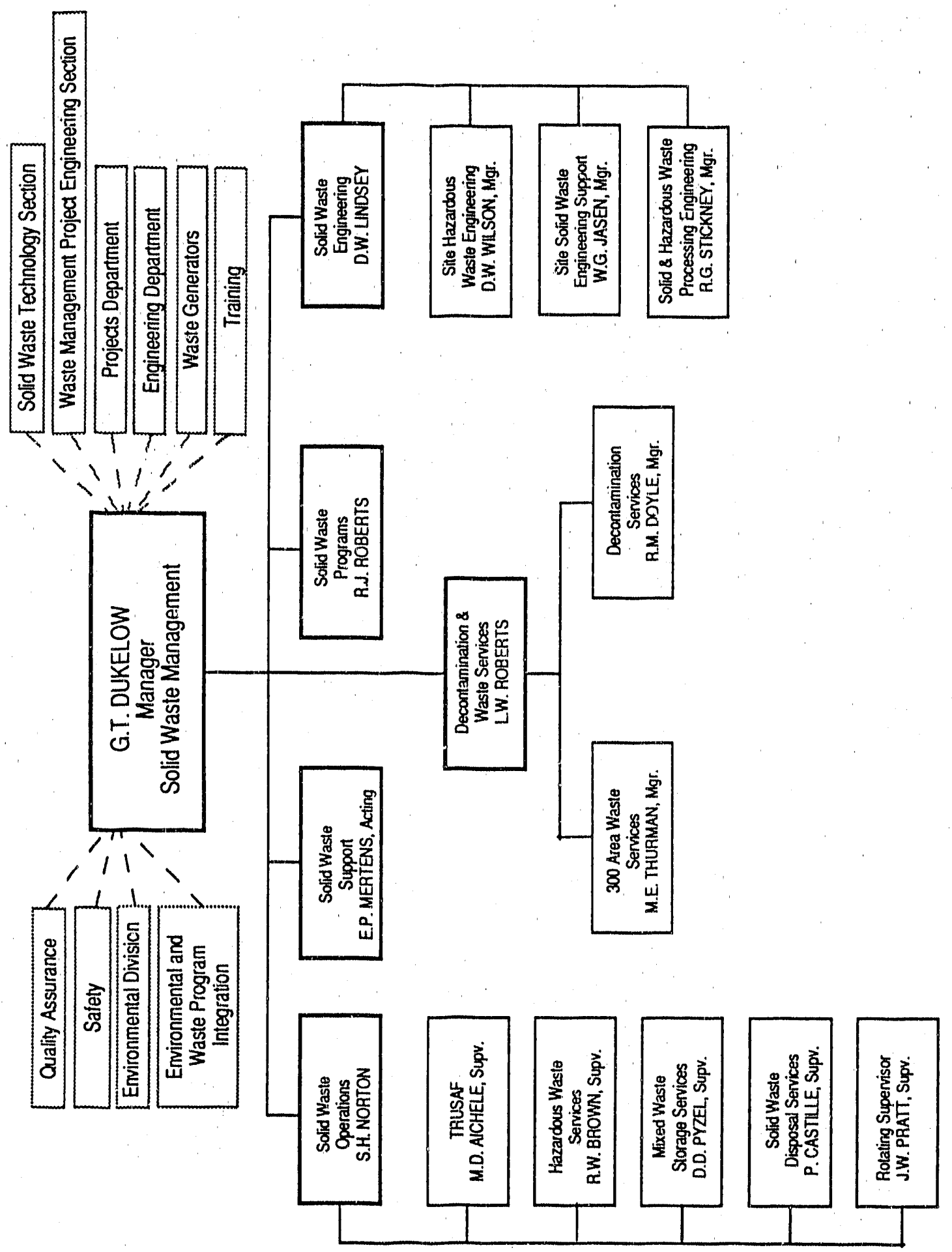


Engineering Department. The groups and sections within the Engineering Department (within the Engineering and Development Divisions, see Figure 2) provide temporary engineering and technical support as necessary, when the timing and scope warrant manpower usage in addition to solid waste functional or matrixed personnel.

Projects Department. This department (within the Environmental and Waste Management Divisions, see Figure 2) is responsible for management of construction-related projects including conceptual and definitive design, procurement, construction, planning, scheduling, and estimating. The department also reviews and comments on engineering studies to help achieve orderly transitions for assumption of project responsibility.

Solid Waste Technology. The Solid Waste Technology Section of the Solid Waste Engineering Group (within the Defense Waste Engineering Function, see Figure 4) is responsible for the planning, identification, assessment, development, testing, and evaluation of new or improved technologies relative to SWM practices at the Hanford Site. These efforts include engineering siudies, functional design criteria (FDC), prototype testing, waste management technology transfer, and preparation of the annual SWM Program Plan.

Waste Management Project Engineering. The Waste Management Project Engineering Section (within the Defense Waste Engineering Function, see Figure 4) provides FDC, engineering study support, and design support for SWM.

Solid Waste Management must interface with many safety and quality assurance organizations to complete nost job tasks. The specific organizations responsible for this function are listed below by organization and charter.

Safety Department. The Safety organizations provide for the independent safety oversight of Westinghouse Hanford operations; dispense radiological monitoring services needed by operations to perform their work safely; provide site-wide fire, ambulance, and hazardous material informational and emergency response services, and fire protection system functional testing; and provide original safety analys is and documentation services as may be required by other organizations.

The specific safety organizations interfacing with SWM are as follows:

- Nuclear Safety. Provides overview and approval of DWM Division design, construction, and operations activities for storage, treatment and disposal of defense waste to ensure compliance with appropriate U.S. Department of Energy-Headquarters (DOE-HQ), DOE-RL, and Westinghouse Hanford safety-related orders and standards applicable to radiological and nuclear safety issues. 
- Safety Analysis and Regulation. Safety Support Services group provides facility and process hazards analysis for all DWM facilities in preparation for required safety analysis documentation per applicable DOE-HQ, DOE-RL, and Westinghouse Hanford orders, standards, and procedures.

- Waste Operations Safety Development. This group provides analys is of facility and process systems safety in preparation for required safety analysis documentation per applicable DOE-HQ, DOE-RL, and Westinghouse Hanford orders, standards, and procedure.

- Industrial Safety and Fire Protection. This organization provides overview and approval of Westinghouse Hanford design, construction, and operations activities to ensure compliance with appropriate DOE-HQ, DOE-RL, and Westinghouse Hanford orders and standards applicable to non-radiological and non-nuclear safety issues.

- Health Physics. This organization is responsible for dispensing radiological monitoring services needed by operations to perform their work safely in compliance with applicable DOE-HQ, DOE-RL, and Westinghouse Hanford orders, standards, and procedures related to radiological and nuclear safety.

Quality Assurance Department. The Quality Assurance organization provides assistance to line organizations for implementation of a problem prevention-oriented quality assurance program that also has the capability of confirming, through independent verification, the attainment of quality. follows:

The Quality Assurance organizations that interface with SWM are as

- Engineering Development Quality Assurance. Construction Projects Quality Engineering provides overview and approval of project. related engineering, design, and construction activities to ensure compliance with appropriate DOE-HQ, DOE-RL, and Westinghouse Hanford orders and standards.

- Chemical Processing Quality Assurance. Technology Programs Quality Engineering provides overview and approval of technology-related engineering, design, and construction activities to ensure compliance with appropriate DOE-HQ, DOE-RL, and Westinghouse Hanford orders and standards.

- Waste Management and Site Support Quality Assurance. Defense Waste Management Quality Engineering provides overview and approval of operations-related DWM Division activities to ensure compliance with appropriate DOE-HQ, DOE-RL, and Westinghouse Hanford orders and standards. 
Training. Training is provided for each individual in SWH; individuals must also complete specific courses related to job requirements. This training is outlined below. The training is provided by a variety of organizations, including line management and several sections within the Support Services Department.

- Fire Extinguisher Safety. Al1 personnel must take this course. This training is renewed annually and is provided on videotape at periodic staff safety meetings. This training fulfills the requirements of DOE-HQ, DOE-RL, and Westinghouse Hanford orders and standards.*

- Non-radiation Worker Training. All personnel must take this course or Radiation Worker Training, depending on job assignment. This training is renewed annually and is administered by the Training Department. This training fulfills the requirements of DOE-HQ, DOE-RL, and Westinghouse Hanford orders and standards.*

- Total Quality Orientation. All personnel must take this course. This training is administered by each Department and fulfills the requirements of Westinghouse Hanford.*

- Alcohol and Drug Awareness. All personnel must take this course. This training is renewed annually and is administered by the Training Department. This training fulfills the requirements of DOE-HQ, DOE-RL, and Westinghouse Hanford orders and standards.*

- Employee Concerns. All personnel must take this course. This training is renewed annually and is administered by the Training Department. This training fulfills the requirements of DOE-HQ, DOE-RL, and Westinghouse Hanford orders and standards.*

- Computer Security Awareness. All personnel must take this course. This training is renewed annually and is administered by the Training Department. This training fulfills the requirements of DOE-HQ, DOE-RL, and Westinghouse Hanford orders and standards.*

- Comprehensive Security Briefing. All personnel must take this course or if it has been $1 \mathrm{yr}$ since the employee has completed this course then they must take the Security Refresher Briefing. This training is renewed annually and is administered by the Training Department. This training fulfills the requirements of DOE-HQ, DOE-RL, and Westinghouse Hanford orders and standards.*

- Building Emergency Plan Checklist. All transfers or new employees must fill out this form with their manager. This training fulfills the requirements of $\mathrm{DOE}-\mathrm{HQ}, \mathrm{DOE}$, RL, and West inghouse Hanford orders and standards.

*Available by interactive terminal through the single umbrella course, Hanford General Employee Training. 
- Facility Orientation Training. All personnel/visitors entering a controlled facility must have Facility orientation Training prior to entry. Facility orientation Training for non-controlled facilities is not required for entry, but is required for any safety-related, facility-specific issues if the employee is to spend most of their time in the factlity. This training is administered by the Plant or Facility Manager and may be delegated to the employee's manager. This training fulfills the requirements of DOE-HQ, DOE-RL, and Westinghouse Hanford orders and standards.

- Radiation Worker Training. A11 personnel entering a radiationcontrolled facility must have this training prior to entry. This training is renewed annually and is administered by the Training Department. This training fulfills the requirements of DOE-HQ, DOE-RL, and Westinghouse Hanford orders and standards.

- Generator Hazards Safety Training. Required for all personnel who work in a HW storage facility. This training is renewed annually and is administered by the Training Department. This training fulfills the requirements of DOE-HQ, DOE-RL, and Westinghouse Hanford orders and standards.

- Hazardous Waste Shipment Certification. Required for all personnel responstble for receiving and shipping HW containers or who supervise such activities. This training is renewed annually and is administered by the Training Department. This training fulfills the requirements of DOE-HQ, DOE-RL, and Westinghouse Hanford orders and standards.

- Hazardous Waste Site Operator, Basic and Advanced. Required for a11 personnel who enter or work in facilities where HW exists. This training is administered by the Training Department and fulfills the requirements of the 0ccupational Safety and Health Act "worker right to know" law as stated in 29 CFR 1910.1200 and the requirements of DOE-HQ, DOE-RL, and Westinghouse Hanford orders and standards. The Basic course is $24 \mathrm{~h}$ in length and the advanced course is $40 \mathrm{~h}$ in length. The selection of basic or advanced training for personnel is based on the severity and length of exposure to hazardous material that the individual is likely to encounter.

Many other organizations within Westinghouse Hanford al so contribute important functions for SWM, but the above organizational interfaces are the most frequent or significant from a standpoint of description of solid waste activities. 
WHC-EP-0363

\subsection{SOLID WASTE MANAGEMENT DESCRIPTION}

\subsection{CURRENT ACTIVITIES}

The operational activities of SWM can be divided into categories of Generator Support, Storage, Treatment, and Disposal (GSTD). This breakdown follows a logical chronological progression of waste from the "cradle-tothe-grave" and matches the RCRA waste management facllity categcries. The "GSTD" format also is consistent with Westinghouse Hanford work breakdown structures (WBS), baseline schedules, and facility designs.

These operations are depicted graphically in the overview diagram in Figure 6. The figure is oriented from left to right in a roughly chronological order corresponding to the realistic "cradle-to-the-grave" handing of waste at the Hanford site. The figure is further divided, from the top down, into the waste types (presented earlier on page 1 of the Scope section) of TRU, LLW, MW, and hazardous. Mixed waste must be further categorized as either TRU/MW or LLW/MW, to meet waste handling requirements. Thus MW is presented in Figure 6 as TRU/MW and LLW/MW.

Generation. The first category depicted in the figure is generation, the point where material is first designated as waste. This includes retrieval of stored TRU waste. Initiaily, the waste must be chardcterized in order to properly classify it. This involves sampling or otherwise determining several physical and chemical characteristics to assign the waste into the categories of LLW, TRU, nonradioactive hazardous, or MW. These categories were defined in section I.B of this Plan. Radioactive waste (LLW, TRU, and RMW) is further divided into "CH" and "RH" dependent on the radioactive dose rate at the waste package surface. The dividing dose rate is $200 \mathrm{mrem} / \mathrm{h}$. Low level waste also has further categorization. Waste that has volume concentrations of certain radionuclides above 1 imits based on tables in 10 CFR 61, Licensing Requirements for Land Disposal of Radioactive Waste, is classified as "greater than class high (GTCH)." Westinghouse Hanford is also considering requiring further classification of LLW, with volume concentrations of radionuclides less than GTCH, into low, intermediate, and high categories, again similar to classification in 10 CFR 61. These classifications are given as interim guidance in Appendix $D$ of WHC-EP-0063-1, Hanford Radioactive Solid Waste Packaging, Storage, and Disposal Requirements. Additionally, hazard categories such as acids, caustics, flammable materials, and oxidizers from U.S. Department of Transportation and state regulations lead to further waste type categorization. Each separate category requires segregation and management according to the particular hazardous and/or radioactive constituent and to permit effective treatment to disposal waste acceptance criteria.

Certification of generated wastes is necessary to ensure that wastes are properly classified and an auditable record is created of such classification. Certification will occur according to acceptance criteria (WHC-EP-0063-1), providing that a waste generator has prepared a certification 
WHC-EP-0363

Figure 6. Solid Waste Overview Diagram.

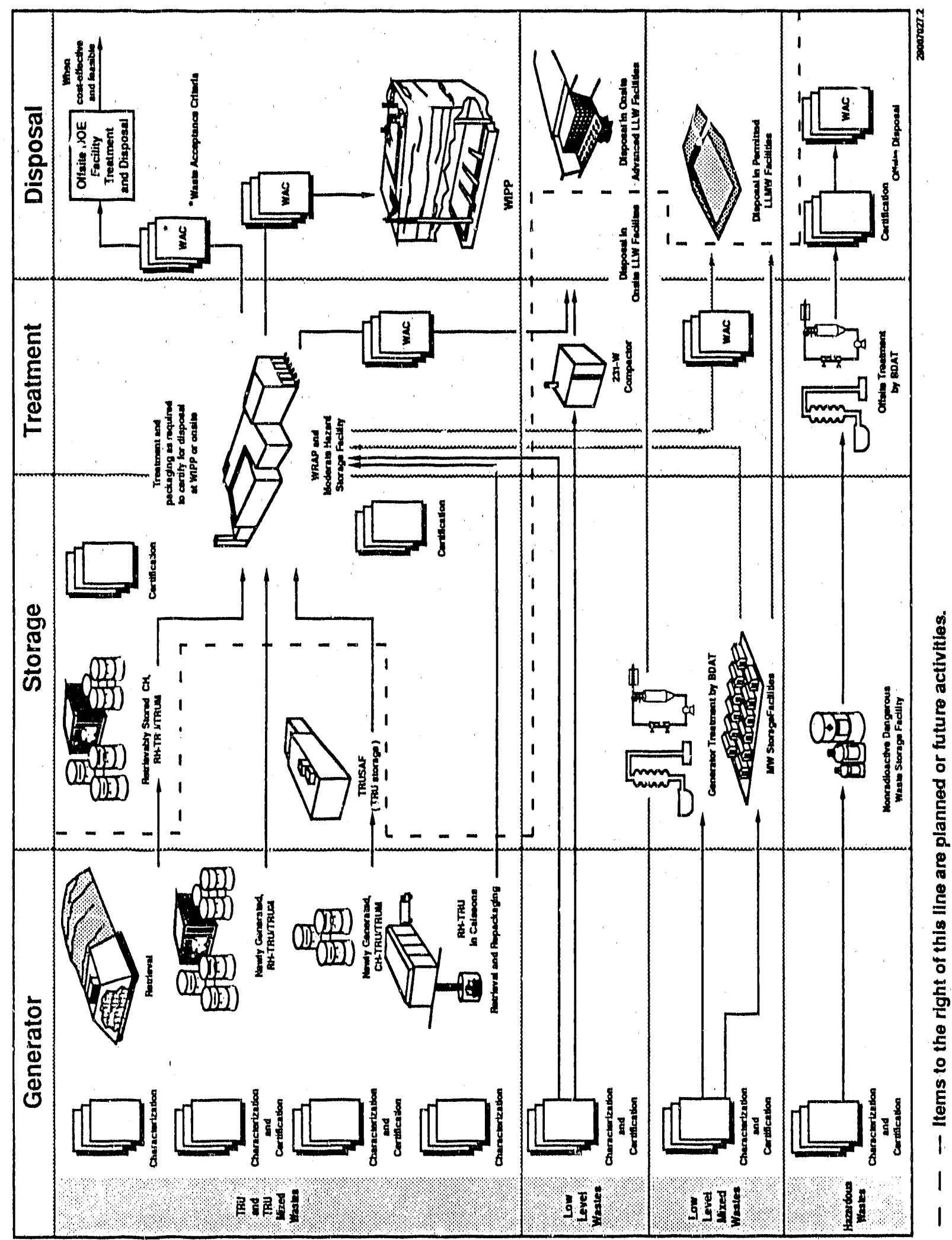


WHC - EP-0363

plan and has passed a generator assessment by Westinghouse Hanford: Transuranic waste must also be certified according to WIPP waste acceptance criteria prior to shipment to WIPP.

Storage. Storage is performed according to the applicable regulations for the waste type. Transuran:c waste is stored temporarily (until shipment to WIPP from the Hanford Site is possible), in buildings or near-surface trenches. All newly generated TRU is stored in 55-gal drums or metal boxes. Drums are certified by the generator and overchecked and stored at the TRUSAF. A future storage facility (the Moderate Hazard Storage Facility [MHSF]) will supplement and probably replace TRUSAF for TRU storage. Low level waste is not stored (although it may accumulate for some days at the generator) but is buried in near-surface trenches. A compaction step may be employed before burial. Solid MW is in temporary storage in the HCWC segregated according to hazardous characteristios of ignitability, corrosivity, reactivity, and toxicity. The Nonradioactive Dangerous Waste Storage Facility (616) contains nonradioactive HW from Westinghouse Hanford.

Treatment. Some small amounts of waste may be treated at the generator site prior to storage and disposal. Treatment of most solid waste at Westinghouse Hanford will be performed at the WRAP Facility, which will be constructed in two modules. Compaction at the $213 \mathrm{~W}$ Facility may be performed prior to disposal for LLW. Module I of WRAP will have the capability to certify retrieved and newly generated drummed CH TRU (and CH TRU MW) and LLW. It will be able to certify newly generated small boxes of TRU but will not handle large boxes of retrieved waste. Module II will process all RH TRU and TRU in containers other than standard waste boxes. Treatment of RH TRU, RH TRU MW and LLW MW wi11 be performed in Module II of WRAP as mandated by best demonstrated avallable techriology (BDAT) from stace or federal regulations. Probable treatment options are thermal treatment, neutralization, and stabilization with grout. Waste acceptance criteria for WRAP will be prepared in the future.

Disposal. Disposal of LLW will continue to be perfurmed in near-surface trenches. The results of performance assessments now being done according to DOE Order 5820.2A will determine the final disposal options for LLW. Advanced low level disposal techniques for some categories of LLW may be required beyond the current trench design, based on the results of performance assessments. I ow level waste in the GTCH category. will be stored pending resolution on a national scale of disposal requirements. Low level RMW will be disposed in liCRA-compliant trenches, following appropriate treatment techniques. Remote-handled LLW and LLW RMW will be disposed in trenches; such disposal is felt to represent the least overall risk due to the high dose rates of the material. Contact-handled and RH TRU, including RMW, will be shipped to WIPP for disposal. Nonradioactive HWs will continue to be shipped offsite to permitted disposal facilities. 


\subsection{SOLID WASTE MANAGEMENT STRATEGY}

The management of solid waste at the Hanford site must be performed in direct response to the current regulatory climate. The broad scope and direction of this climate is clear but the details of regulatory compliance on the basis of an individual facility or waste container are often unclear or defined by negotiation among several responsible public and private entities. Consequentiy the course of SWM strategy for the future is set in a broad sense but much facility and waste stream definition remains to be determined.

The regulatory environment driving SWM practices at the Hanford Site is multi-faceted. The RCRA and DOE Orders 5820.2A and 5480.1B set the standards for all hazardous, radioactive, and RMW management practices. The Tri-Party Agreement (Ecology et al 1989) al so sets standards and schedules for Hanford SWM, which are critical on a local and regional scale. Implementation of the riational DOE commitment to waste cleanup is determined by the DOE-HQ Environmental Restoration and Waste Management Five-Year Plan (FYP), an annually updated document.

Reduced to a single basic component, the Hanford SWM strategy is a "cradle-to-grave" tracking and management system, as mandated by the RCPA. The specific activities within the "cradle" (waste generators) and prior to and at the "grave"(disposal facilities) are dictated by priorities within the regulatory environment. These priorities determine the allocation of funding and the thus the schedule for cradle-to-grave management.

The FYP contains a DOE-wide priority system to guide activities and to support budget requests. This system was developed in cooperation with Indian Tribes, local and state agencies, and national interest groups. Work at each site $w^{\prime} 11$ be funded in direct relationship to priority level. The priorities are:

1. Necessary to prevent near-term adverse impacts to workers, the pubilic, or the environment. Examples include containment to prevent the spread of contamination, actions to prevent or minimize releases to the environment, and ongoing waste management activities required to maintain safe conditions. Also included in Priority 1 are ongoing activities which, if terminated, could result in significant program and/or resource impacts.

2. Required to meet the terms of agreements between DUE and local, state, and Federal agencies. These agreements represent legal commitments to complete activities on the schedule agreed to by DOE.

3. Required for compliance with external environmental regulations that were not captured by Priority 1 or 2 . Other actions included in Priority 3 are compliance with DOE Orders that implement external regulations or that set specific DOE regulatory standards, actions that would reduce risks or costs, and actions that would prevent disruption of the DOE mission. 
4. Activities that are not required by regulation but would be desirable to do. Examples include complying with DOE Orders that are more stringent than external regulations, implementing good management practices, reducing personnel exposures below levels required by regulations or standards, and acceierating actions to satisfy an agreement or milestone ahead of schedule.

A further framework for SWM practices are the priorities recorded in the WAC 173-303-140:

1. Reduce waste generation

2. Recycle usable waste constituents

3. Treat wastes through physical, chemical, or biological means

4. Incinerate combustible wastes

5. Stabllize and solidify wastes

6. Dispose of residues from treatment processes in a landfi11.

With the above framework and constraints, the strategy for SWM becomes an evolutionary process as appropriate tactics are developed to deal with existing and newly generated wastes. These tactics differ with the point in the "cradle-to-grave" process and with differing waste type.

The initial tactic is to ensure the greatest accuracy in the forecasts and descriptions of Hanford solid wastes. This is necessary to accurately size facilities and processes to handle the required waste volumes within the required time frames, while at the same time avoiding unneeded and expensive processing capacity. Current forecasts contain a great deal of uncertainty in the amounts of future waste, particularly due to unknowns in volumes from decontamination and decommissioning and in volumes resulting from future treatment methods. This uncertainty jeopardizes the accurate design of future facilities.

The annual waste forecast information requested from each onsite or offsite waste generator has been updated to better provide the hazardous and radioactive waste data needed for inventory data base $\left(I^{\prime}, B\right)$ submittals, characterization studies, facility plans, and performance assessments. A Solid Waste Volume Projection Model has been developed to allow estimates of volumes by waste type including the results of treatment operations. The current information data base, the Richland Solid Waste Information Management System (R-SWIMS), is being updated to have near-real-time cradle-to-grave waste tracking capability. The resultant system will be implemented in FY 1991 as the Radioactive Solid Waste Tracking System.

The generator tactics portion of the SWM strategy will include an aggressive waste minimization program and waste segregation policies for generation and storage facilities. A draft Hanford Site Waste Minimization and Pollution Prevention Awareness Plan has been completed in response to 
the DOE Draft Waste Reduction Policy and Waste Minimization Guidance. This document will provide recommendations on the conduct of an effective waste minimization program. Westinghouse Hanford waste generators are preparing detailed waste minimization plans at the facility or activity level.

Additional emphasis will be placed on certification programs for each generator to ensure that they can meet waste acceptance criteria.

Storage tactics include an assessment of the interface requiraments and throughput requirements for moving stored and newly generated TRU waste from storage areas through the WRAP Facility to the WIPP Site. This necessitates knowledge of the required annual throughput to work off TRU waste prior to WIPP closure, and design and construction of necessary capacity in storage facilities and in WRAP. The facility designs must be coupled to provide maximum efficiency, and minimize transportation. Low level RMW requires accurate forecasting of MW volumes and characteristics and design and construction of adequate RCRA-compliant storage facilities to accommodate generated waste until work off can begin. Land disposal restricted RMW will continue to be stored pending availability of BDAT standards and appropriate treatment capability at Hanford.

Treatment options require surveying of technologies at other DOE sites and within the private sector to utilize the most effective available techniques. Some treatment at other locations may be feasible, but the bulk of waste treatment is expected to occur at Hanford. Treatment technologies will be selected on the bas is of ability to meet RCRA requirements, life cycle cost, and acceptance by the public and regulatory agencies. Treatment of MW will be done primarily in WFAP Module II, to be operational in 1999. Some treatment capability may be available earlier, to allow disposal of RMW in the W-025 ilixed Waste Disposal Trerch, planned for completion in 1992.

Tactics for disposal at Hanford will include el imination of 1 and disposal of untreated RMW, by usage of appropriate BDAT treatment and disposal in permitted facilities. Transuranic waste, including mixed TRU, will be shipped to WIPP. Low level waste will be continue to be disposed in near-surface trenches, whose design will depend on the results of performance assessments now being carried out. Nonradioactive HW will continue to be shipped offsite for disposal. In all disposal activities, waste acceptance criteria for the disposal facility must be recognized and met, including criteria development for onsite facilities.

The activities described above are part of an integrated and consistent approach toward implementation of SWM activities at the Hanford Site leading to final waste disposal. The activities have been examined in meetings with participation of interfacing organizations and needs for future studies and efforts have been quantified. These needs will be translated into the baseline for the succeeding fiscal years as budgets and priorities permit.

\subsection{SCHEDULE}

Schedules for the SWM function are prepared by the Program Scheduling Section for the WMD. 
A summary schedule for SWM is given in Figure 7 . It is divided into the categories of GSTD as was the overview diagram in Figure 6 . In addition, supporting documentation efforts are collected under another category termed Generaj Program Support. Two other facility-related categories are shown in the schedule of 1) Permitting and Closure Plans and 2) Corrective Actions. They are presented as separate categories rather than with the appropriate storage, treatment, or disposal facility due to their significance in achieving RCRA compliance. These seven categories also align well with the WBS funding categories.

The milestones in the summary schedule will be discussed briefly in the next sections, by fiscal year. In some cases, explanatory information or activities not on the summary schedule will be presented for clarity.

\subsubsection{Fiscal Year 1989 Accomplishments}

The significant accomplishments of the SWM function during FY 1989 will be summarized in this section.

\section{Generator}

- The annual TRU Certification Report, detailing certification activities for newly generated CH TRU drums, was released.

- The annual report on number of $\mathrm{CH}$ TRU drums assayed in the TRUSAF facility was issued.

- The annual volume forecast from waste generators was revised to include greater detail needed to accurately size and scope future facilities, particularly for HW components.

- The waste volume information for the annual IDB submittal was provided to WIPP and Oak Ridge National Laboratory (ORNL).

\section{Storage}

- Six low flashpoint storage modules were put into place in the HCWC.

- The 2401-W and 2402-W RMW storage buildings (thirteen 4,000 $\mathrm{ft}^{2}$ buildings) were in put into operation.

- Design was completed on Project W-016, Phase I, a 34,000 $\mathrm{ft}^{2}$ RMW storage facility.

- A summary of the history, functions, and capabilities of the HCWC was issued as an internal report.

The Part B Permit for the 616 Nonradioactive Dangerous Waste Storage Facility was submitted to the Ecology and the EPA (Region X). 
Figure 7. Solid Waste Management Summary Schedule.

\section{Solid Waste Management Program Summary Schedule}

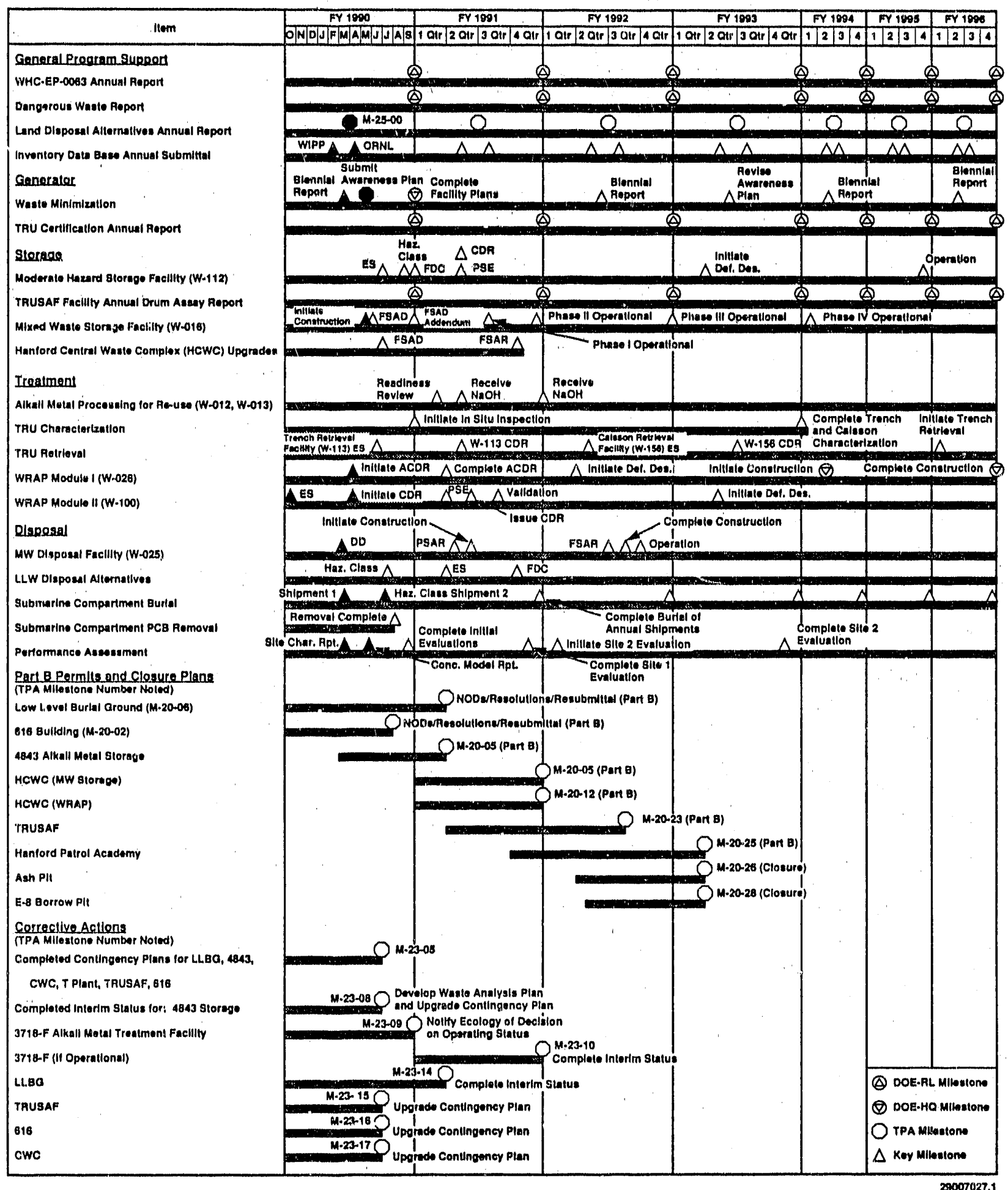


WHC-EP-0363

\section{Treatment}

- A draft engineering study for WRAP Module II, including treatment options was prepared.

- A revised FDC for WRAP Module I was issued. This was based on an FDC prepared in 1986.

- The efforts necessary to retrieve the TRU waste now in underground trenches is considered in the "Treatment" category in the Solid Waste WBS. It should be noted that during the actual retrieval the waste will functionally be newly generated waste. This retrieval is divided into three phases. Phase $I$ is a planning effort which includes an overall plan for the retrieval work, a study of existing records for the stored TRU, and a $\mathrm{plan}$ for sampling the waste prior to full scale retrieval. Drafts of all three reports were done during FY 1988 and the overall plan was issued as an internal report. During FY 1989, the sampling plan was issued as a publicly released document.

- The storage and distribution system for $\mathrm{NaOH}$ processed from Fermi, Hallam, and SRE sodium stored at Hanford was completed (projects W-012 and W-013).

- Module I of WRAP was validated for FY 1991 design.

\section{Disposal}

- Design was initiated on the W-025 RMW Disposal Trench for $\mathrm{CH}$ waste. This trench is to be fully RCRA-compliant with a liner and leachate collection system. Waste will be treated prior to disposal.

- Work on the Part B Permit application for the Low Level Burial Grounds continued to support its submittal in December 1989.

- Burial of defueled United States Navy submarine reactor compartments in the low level burial grounds was initiated with two shipments.

\section{General Program Support.}

- Demonstration of a sorting table for LLW waste segregation was planned and sorting table was installed.

- Upgrade of the R-SWIMS database was begun.

- A draft waste minimization and pollution prevention awareness guidelines document was prepared and reviewed.

- The first revision of the criteria document for storage and disposal requirements, "Hanford Radioactive Solid Waste Packaging Storage, and Disposal Requirements," WHC-EP-0063-1, was released. 
- The annual report on dangerous waste received, stored, and shipped offsite for disposal was issued.

- The Solid Waste Projection Model was developed to project the volumes of waste requiring storage, treatment, and disposal.

\subsubsection{Expected Fiscal Year 1990 Accomplishments}

The planned accomplishments of the SWM function during FY 1990 are listed below. Activities completed at the time of completion of this Plan are so designated.

\section{Generator}

- The annual TRU Certification Report, detailing certification activities for newly generated.CH TRU drums, will be released.

- The annuat report on number of $\mathrm{CH}$ TRU drums assayed in the TRUSAF facility will be issued.

- The waste volume information for the annual IDB submittal was provided to WIFP and ORNL.

\section{Storage}

- Construction will be initiated on the W-016 Phase I RMW storage building.

- Design wi11 be completed on the W-016 Phases II, III, IV, RMW storage buildings.

- An engineering study will be completed on Project $W-112$, the MHSF, for storage of CH TRU waste in support of WRAP and TRU waste retrieval operations.

\section{Treatment}

- A readiness review for operation of the sodium hydroxide processing facilities will be completed. The initial shipment of sodium hydroxide from Idaho National Engineering Laboratory will be received at Hanford.

- Advariced studies for WRAP Module I will be completed, and the advanced conceptual design report (ACDR) for WRAP I will be initiated.

- An engineering study for WRAP Module II was issued, and the FDC for WRAP II will be issued. The conceptual design report (CDR) will be initiated during FY 1990. 
- The overall plan and the records study for the TRU characterization and sampling of retrievably stored TRU waste were issued as publicly released documents. Sampling of retrievably stored ThU for characterization purposes will be initiated.

\section{Disposal}

- Removal of PCB-contaminated felt in submarine reactor compartments, required by state dangerous waste regulations, will be complete in FY 1990 .

- After a cessation of design activity in FY 1989, design of the W-025 RMW disposal trench was resumed by Golder \& Associates. The design will be complete in FY 1991.

- An engineering study for the next generation of low level disposal facilities will be issued.

- A site characterization report to serve as a basis for LLW disposal performance assessments will be completed, as well as a letter report on results of performance assessment modeling.

\section{General Program Support}

- The annual report on dangerous waste received, stored, and shipped offsite for disposal was issued.

- The first annual status report on alternatives to land disposal of solid RMW was issued to the EPA (Region $X$ ) and Ecology. This was Tri-Party Agreement Milestone M-25-00A (Ecology et ai 1989).

- The biennia? waste minimization report was issued.

- The Westinghouse Hanford Waste Minimization and Pollution Prevention Awareness Plan was issued.

- The Westinghouse Hanford facility specific waste minimization plans will be complete.

- The revision of the criteria document for storage and disposal requirements, "Hanford Radioactive Solid Waste Packaging Storage, and Disposal Requirements," WHC-EP-0063-2, wil1 be completed.

- A Basic Ordering Agreement contract was put in place to provide engineering expertise to support SWM efforts.

\section{Permitting}

- The Part B permit for the 616 Butlding, the Nonradioactive Waste Storage Facility, will be resubmitted after final resolution of comments and notices of deficiency. 
- Work on the Part B Permit for the 4843 Alkali Metal Storage Facility will be initiated.

- The Part B Permit for the Low Level Burial Grounds was submitted. Final resolution of all Notices of Deficiency is expected in FY 1991.

\section{Corrective Actions}

- Contingency plans will be completed for the following Solid Waste facilities: Low Level Burtal Grounds, T Plant, TRUSAF, 616 Building, HCWC, and the 4843. Building. These plans are a state requirement for all interim status facilities.

- Interim status (compliance with a11 state and federal environmental regulations required while Part B operating permits are pending) will be completed for 4843 Alkali Metal Storage, TRUSAF, the 616 Building, and the HCWC.

\subsubsection{Expected Fiscal Year 1991 Accomplishments}

The achievements expected in FY 1991, the next year after the issuance of this Plan, are given below.

\section{Generator}

- The annual TRU Certification Report, detailing certification activities for newly generated CH TRU drums, will be released.

- The annual report on number of $\mathrm{CH}$ TRU drums assayed in the TRUSAF facility will be issued.

- The waste volume information for the annual IDB submittal will be provided to WIPP and ORNL.

\section{Storage}

- The Phase II portion of the W-016 RMW storage buildings will be operational.

- Work on the Part B Pernit for the HCWC will be initiated.

- Work on the Part B Permit for TRUSAF will be initiated.

"Th The Part B Permit for the 4843 Facility will be submitted.

\section{Treatment}

- The ACDR for WRAP Module I will be issued, and definitive design initiated. 
- The CDR for WRAP Module II will be issued, and Module II will be validated for design.

- Work on the Part B Permit for WRAP will be initiated.

- Sampling of retrievably stored TRU waste will be completed.

- Sodium hydroxide processed from Hanford sodium will be received for usage in PUREX.

\section{Disposal}

- Construction of the W-025 RMW disposal trench will be initiated.

- The Part B Permit for the Low Level Burial Ground will be issued.

- The FDC and CDR for the next generation of low level disposal faciltties will be completed.

\section{General Program Support}

- The annual report on dangerous waste received, stored, and shipped offsite for disposal will be issued.

- The annual status report on alternatives to land disposal of solid RMW will be issued to the EPA (Region X) and Ecology. This will be Tri-Party Agreement Milestone M-25-00B.

\subsubsection{Forecast Outyear Accomplishments}

The outyear accomplishments of SWM for FY 1992 and beyond are enumerated. These will be tasks of major significance and thus fewer in number on an annual basis than the FY 1989-1991 efforts. Annual report issuances will not be discussed.

\section{FY 1992}

- The W-025 trench for disposal of RMW will be operational.

- The Part B Permits for the HCWC, WRAP, the Hanford Patrol Academy Demolition Sites, and TRUSAF Will be submitted to Ecology and Region $X$ of the EPA.

- The closure plans for the E-8 Borrow Pit Demolition Site and the Ashpit Demolition Site will be submitted to Ecology and Region $X$ of the EPA.

- Construction on Phase III of the W-016 RMW storage building will be complete. 
WHC-EP-0363

FY 1993

- Construction of Phase IV of the W-016 RMW storage building will be complete.

FY 1994

- Construction will begin on the 618-11 and Alpha Caisson RH TRU retrieval facilities.

FY 1996

- Full scale retrieval of retrievably stored TRU in trenches will be initiated.

- WRAP Module I will be operational.

- The initial TRU waste shipment to WIPP will occur.

FY 2002

- Retrieval of RH TRU in alpha caissons and the 618-11 burial ground will be initiated.

FY 2013

- The final shipment of TRU waste to WIPP will occur and the WIPP site will be closed.

\subsection{COST}

\subsubsection{Work Breakdown Structure}

The WBS used by the WMD to control and describe its costs is shown in Figure 8. The WBS elements support the top-level mission of the Division to provide for safe treatment, storage, or disposal (TSD) of wastes which have accumulated over the past 46 yr of defense material production. The programs under the control of SWM are highi ighted.

The WBS identifies the major elements of work to be performed. This structure is the single common structure for definition and control of all Division work. The siructure represented in Figure 8 envelopes a lower level WBS administered by end functions, shown for SWM in Figure 9.

A WBS Dictionary, or description of activities in each WBS block, is given below. 


\section{Figure 8. Defense Waste Management Division Work Breakdown Structure.}

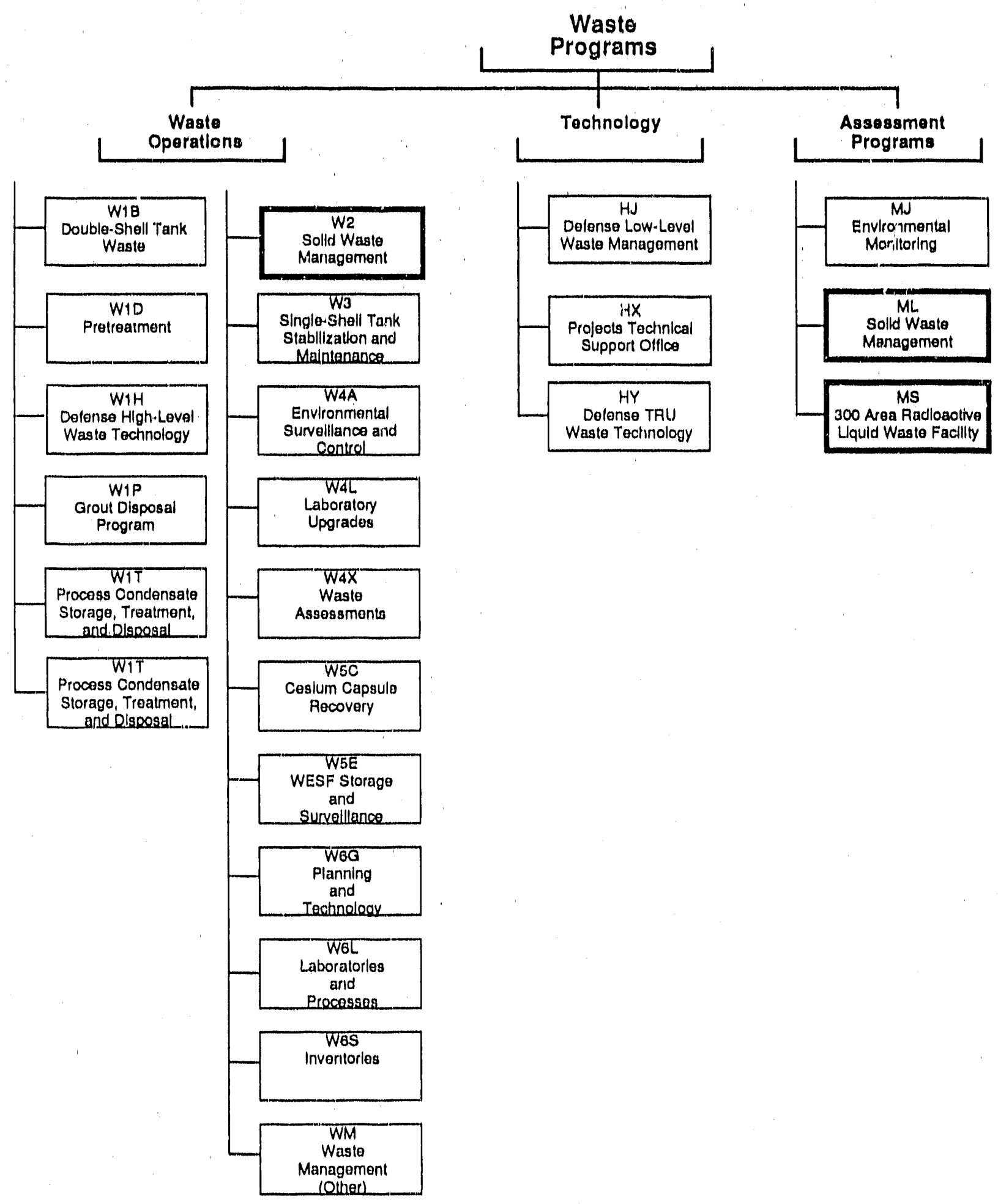


Figure 9. Solid Waste Management Work Breakdown Structure.

\section{Solid Waste Programs}

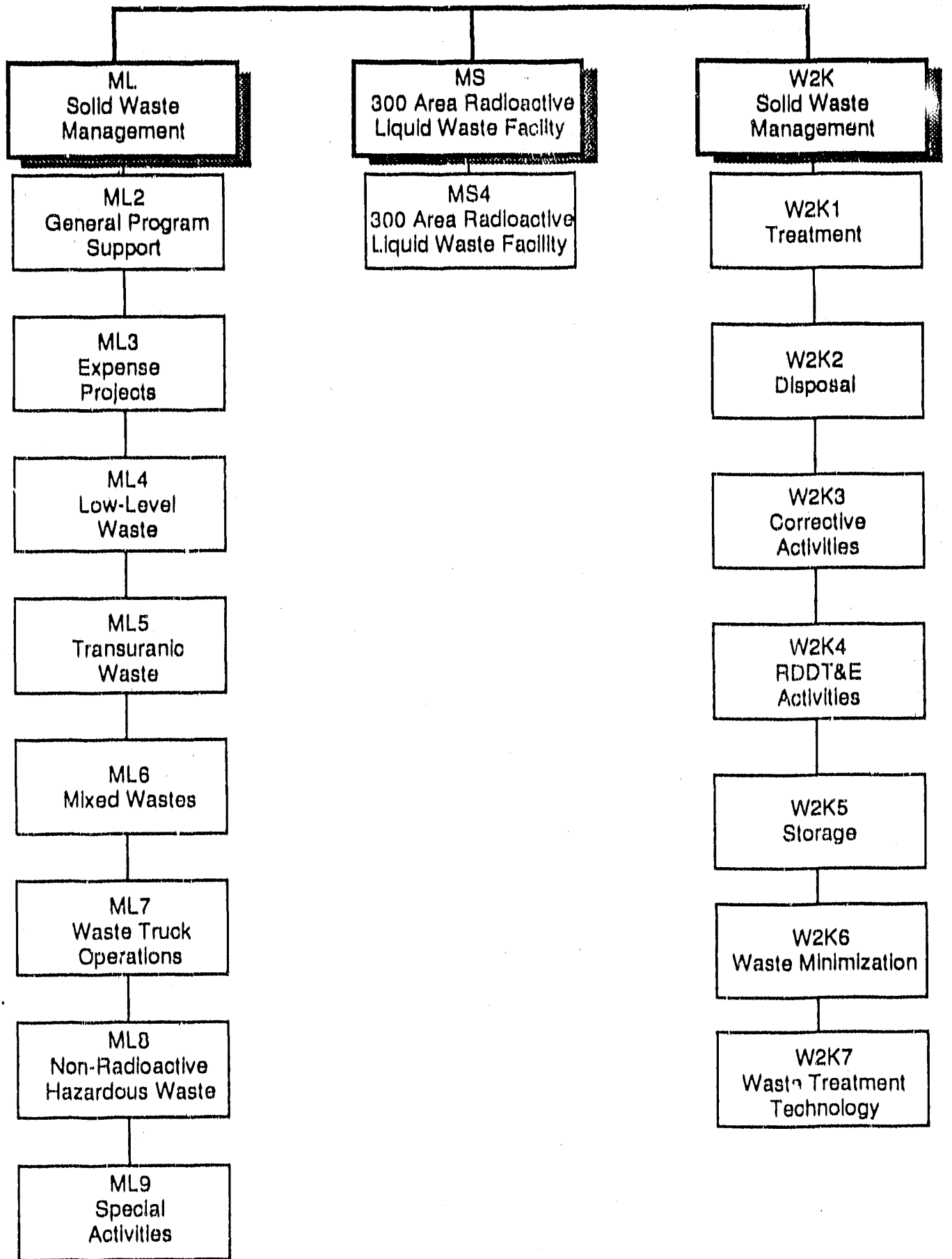




\section{W2K Solid Waste Management}

The objective of this WBS category is to achieve compliance with the requiled regulations through the design, construction and operation of solid waste TSD facilities including completion of RCRA permitting actions. This category is funded through direct budget approprtations.

\section{W2K1 The Treatment activity supports:}

- Studies, design documents, equipment development, and operational activities for retrieval of post-1970 stored TRU waste from 26 trenches, four alpha caissons, and 618-11 caissons and trenches.

- Pre-project and project support work required to design, construct, and operate WRAP Modules I and II. This activity inciudes all of the operating and capttal equipment funding, including engineering studies, FDC, CDRs, ACDRs, environmental evaluations, safety analyses, quality assurance reviews, and safety reviews.

- Operation and maintenance of a light duty box compactor for the volume reduction of radioactive LLW, including installation of a sorting table to allow reuse of clean tems, and technical coordination with waste generators for volume reduction techniques.

W2K2 The Disposal activity supports:

- Annual preparation of a report surveying Hanford contractor efforts to identify alternatives to land disposal of RMW. Hanford is currently out of compliance with state and federal regulations prohibiting disposal of RMW prior to appropriate treatment, and also prohibits storage unless it is for the purpose of specifted treatment and disposal. The Tri...Party Agreement allows, however, continued storage as long as alternatives are being actively investigated.

W2K3 The Corrective Activities category supports RCRA permit applications and closure plans for existing and new solid waste facilities, including resolution of Notices of Defictency.

W2K4 The Research, Develop, Test, and Evaluate (RDT\&E) activity supports design and development tasks funded under new requests from the RDT\&E account.

W2K5 The Storage activity provides for engineering studies, FDCs, CDRs, review and support activities, and capital funding to design, construct, and operate factitites to store RMW, TRU, and GTCH waste. This includes operations of the 616 Butlding and TRUSAF. The HCWC RMW facllities, however, are funded under the ML generator assessments program.

W2K6 The Waste Minimization Activity supports processing of radioactively contaminated metallic sodium stored at Hanford by conversion to sodium hydroxide and usage at PUREX for waste neutralization. 
W2K7 The Waste Treatment Technology activity provides for acquisition of retrievabiy stored TRU waste characterization data to support design of facilities for management of TRU waste, and general baseline activities supporting WRAP design.

\section{Solid Waste Management}

The objective of this WBS category is similar to that of W2K; the ML funding comes from waste generator assessments rather than direct budget appropriations.

ML2 The General Program Support activity covers general naeds of Solid Waste that overlap from one waste type to another. Included are:

1. General supervision

2. Burial Ground operations

3. DOE Order 5820.2A Implementation requirements (i.e. generator inspections, database management, volume reduction studies, storage/disposal requirements and performance assessments)

4. Safety/Quality Assurance support

5. WRAP studies and design activities.

ML3 Expense Projects activity supports Project W-025, the RMW Disposal Facility, a RCRA compliant trench to handle CH and RH mixed LLW.

ML4 The LLW activity includes studies to improve effictency of the $213 \mathrm{~W}$ box compactor to maximize usage of land for LLW disposal.

ML5 The TRU Waste category envelopes activities and planning for storage of TRU waste above ground to comply with current regulations, including alternatives to RH TRU caisson storage.

ML6 Mixed Wastes activities includes design, construction, and operation of the RMW storage facilities in the HCWC.

ML.7 The Waste Truck Operations activity provides a waste collection service for generators of LLW at the Hanford Site.

ML8 The Nonradioactive HW category involves activities to manage, store, and ship nonradioactive HW.

ML9 This miscellaneous category is reserved for items which are not foreseen at the beginning of the fiscal year and do not fit any other WBS. An example is the disposal of the submarine reactor compartments. 


\section{MS 300 Area Radioactive Liquid Waste Facility}

MS4 This activity provides for the collection of liquid waste from the 300 Area laboratories and for the transfer of the waste to the DSTs in the 200 Ârta.

In adidition to the above programs, Solid Waste personnel are performing work during FY 1990 supporting the MH and HY programs. The Westinghouse Hanford Waste Minimization Proyram is coordinated by SWM from MH, which is the Hanford Environmental Management Program. An analysis of treatment technologies for spent resins waste is being performed under HY (Defense TRU Technology) funding. Funding from areas outside the Division also exists. Work on disposal of reactor core baskets from Knolls Atomic Power Laboratory is under the TG9 WBS.

\subsubsection{Work Breakdown Structure Implementation}

Below the Level 2 WBS, costs and work scope are divided into and defined through Cost Accounting Authorizations (CAA) which implement planning and include all procurement actions and commitments. They are prepared and issued by activity managers for each cost account and authorized by the appropriate program or project manager. The CAAs contain the target budget for the cost account, the schedule in terms of the major milestones, and a scope description. Their issuance authorizes work performance.

The work scope defined in the CAA is further broken down in a cost Accounting Pyan (CAP), which is the working level control point for cost, schedule and technical program parameters. The CAPs contain statements of work to be performed by single organizations with a month-by-month cost analysis. The work and task packages in the CAPs are the lowest level of scheduled work.

The cost, schedule and funding baselines established in the site Specific Plan (SSP) and other tCp-level Westinghouse Hanford planning documents are translated into the CAAs and CAPs and performance is measured through the Management Control System (MCS), written to incorporate the requirement of the DDE Cost and Schedule Conirol Systems Criteria for Contract Performance Measurement. Variances between planned and actual performance are analyzed through the MCS and corrective actions are implemented.

\subsubsection{Budgets}

The budgets from the FY 1991 FYP submitted for programs under SWM Control are given in Tables 1 through 3. The costs are in FY 1990 dollars. A summary for SWM is shown in Table 4 . 
Table 1. Solid Waste Management (ML) Budget.

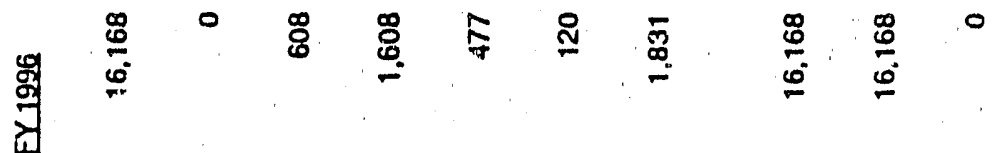

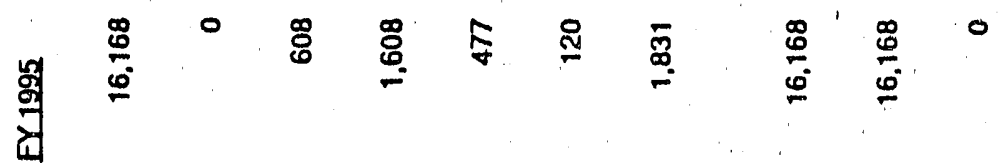

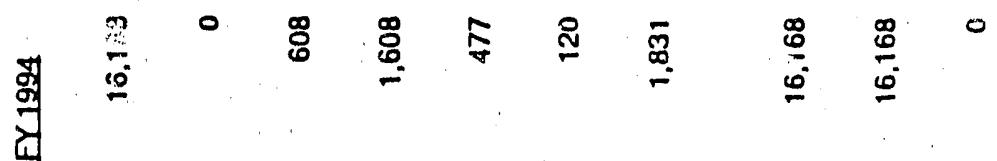

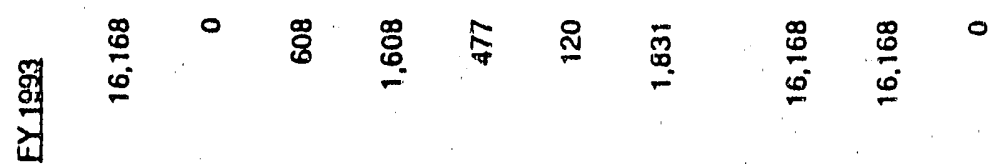

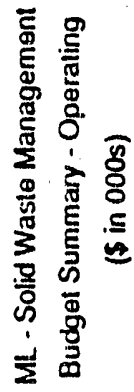

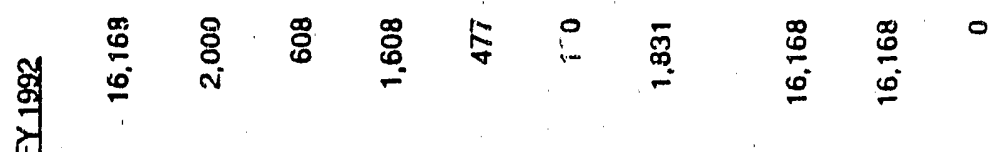

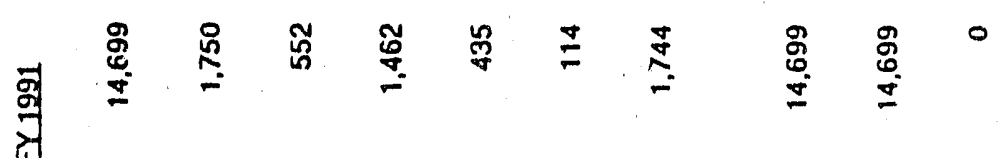

券 兽

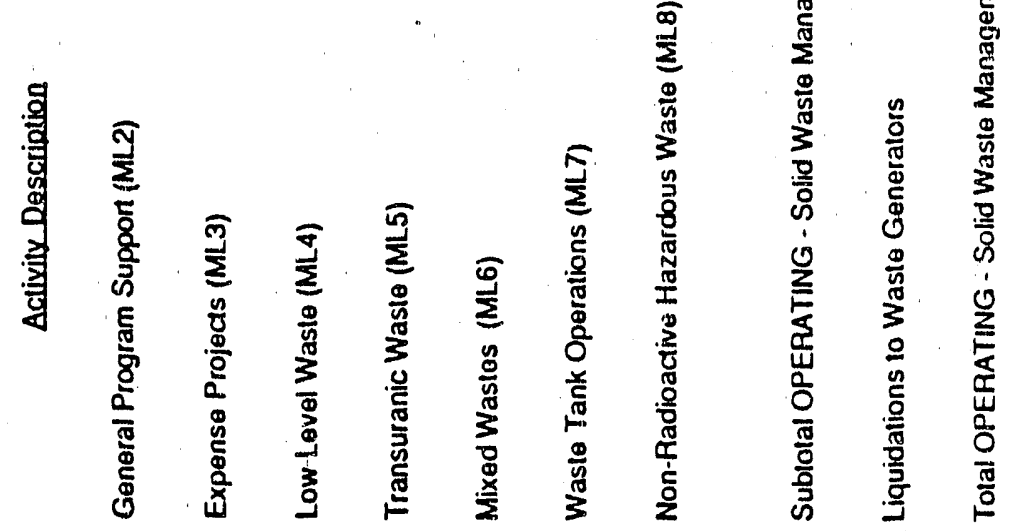




\section{WHC-EP-0363}

Tab1e 2. Solid Waste Management (W2) Budget.

(sheet 1 of 2)

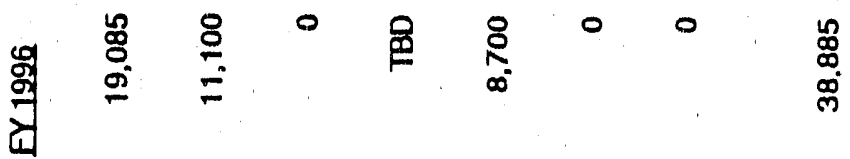

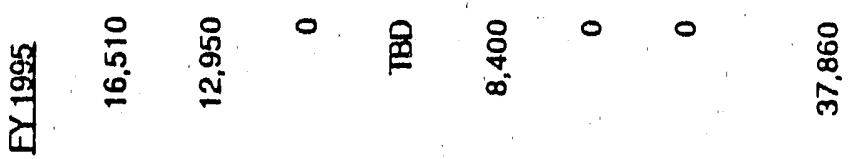

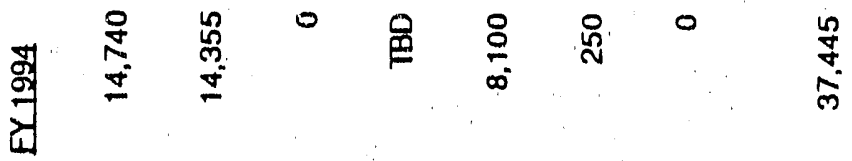

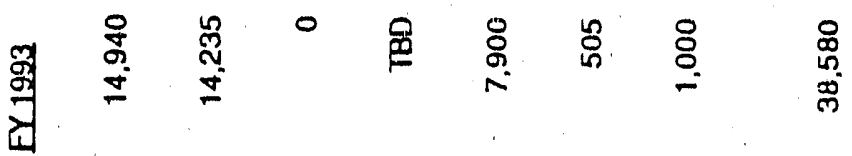

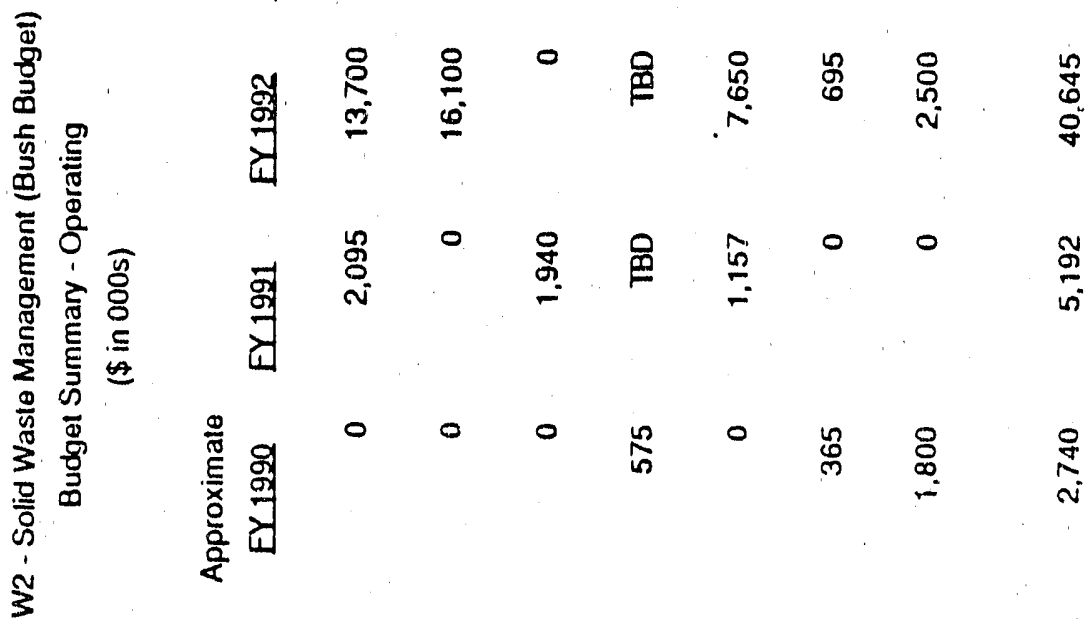

章

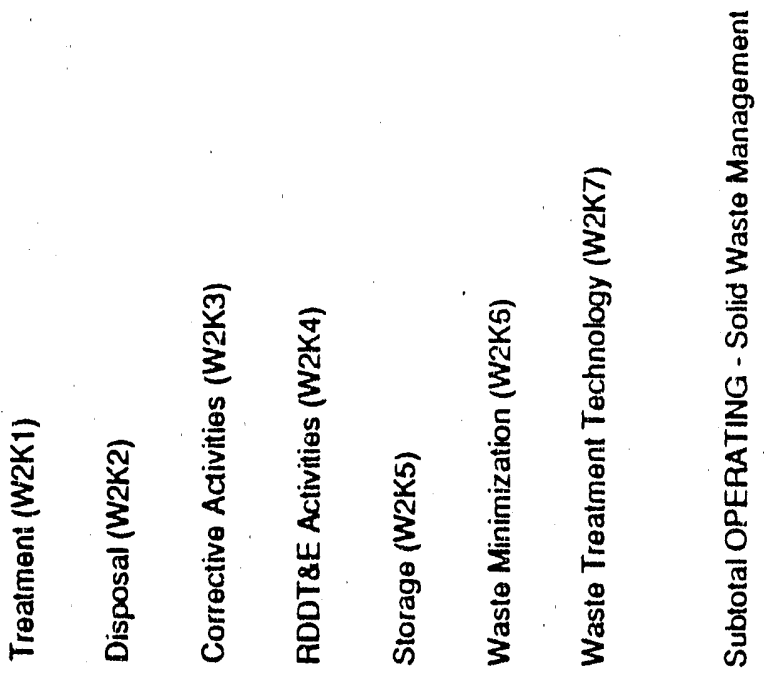


Table 2. Solid Waste Management (W2) Budget.

(sheet 2 of 2)

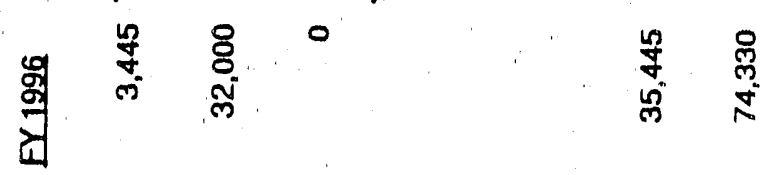

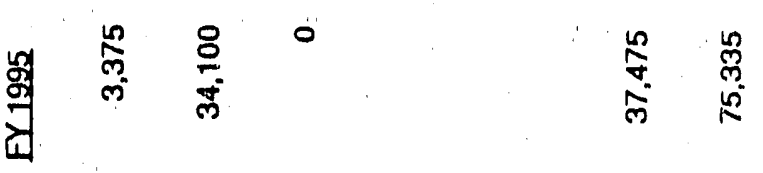

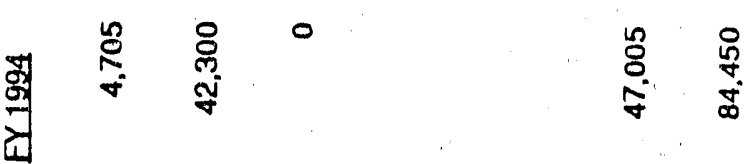

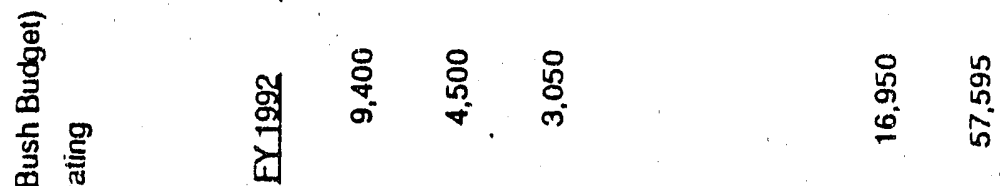

‡.

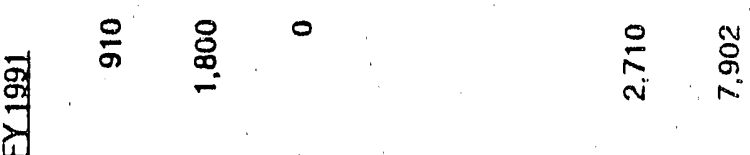

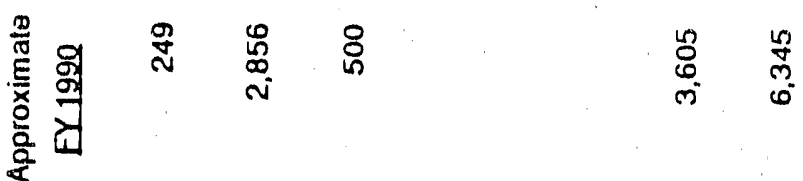

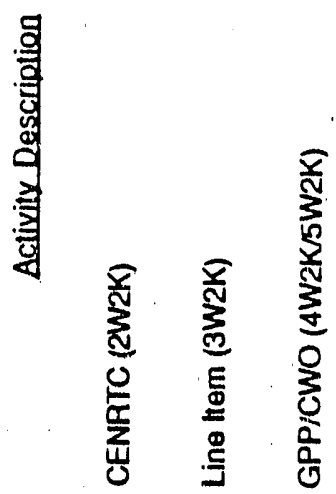

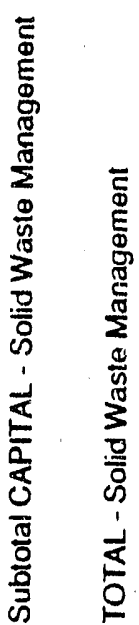


WHC-EP-0363

Table 3. Solid Waste Management (MS) Budget.

章 $\stackrel{0}{\circ}$ N 0 :

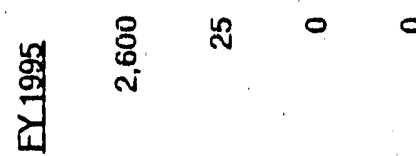

ָับ

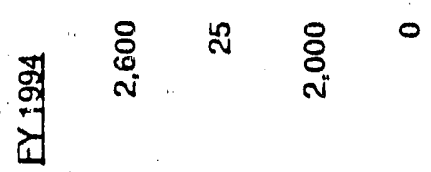

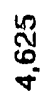

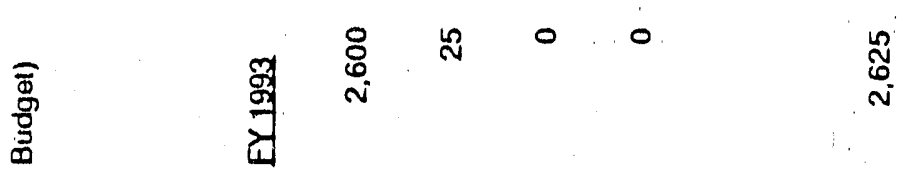

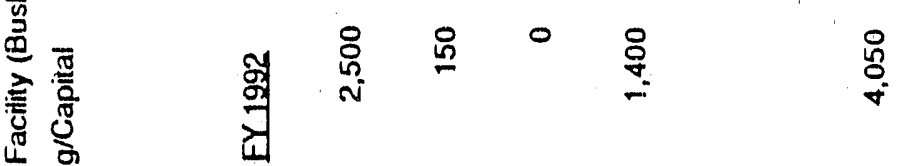

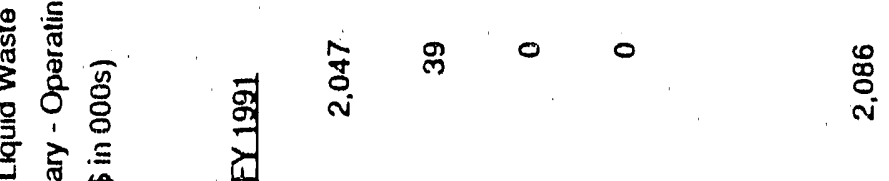

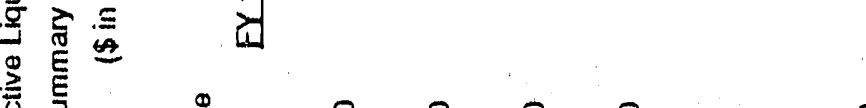

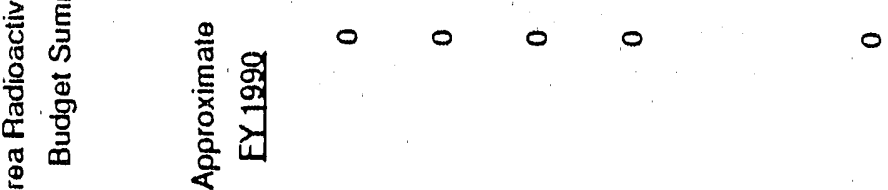

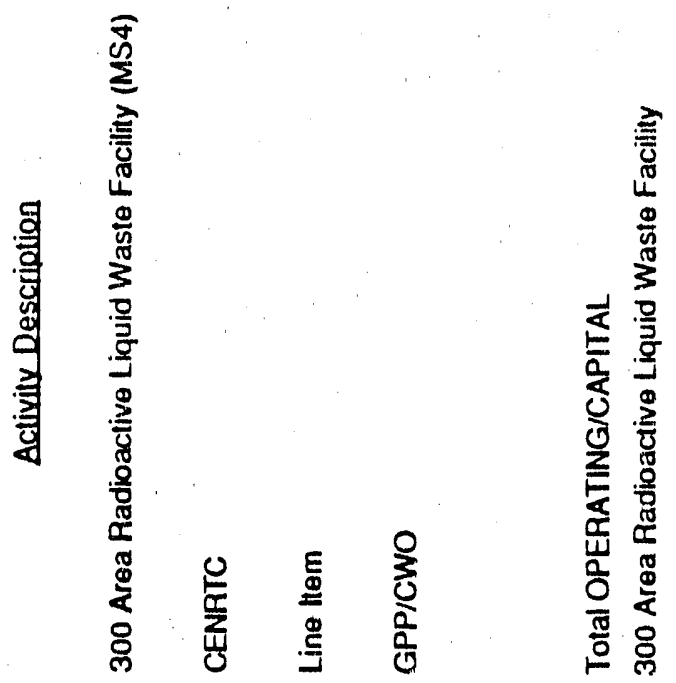


Table 4. Summary Budget.

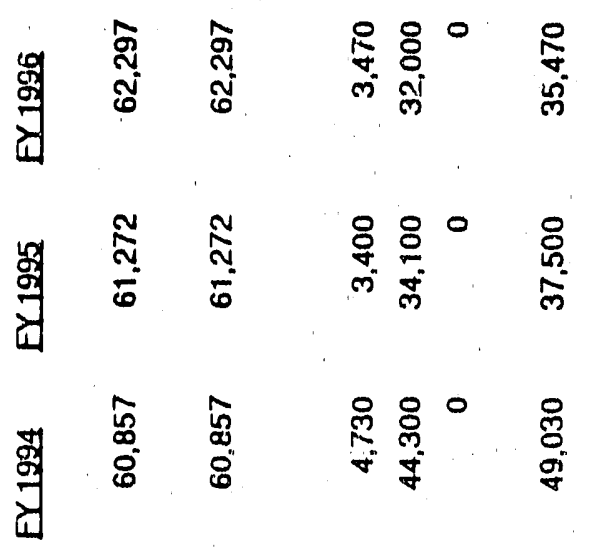

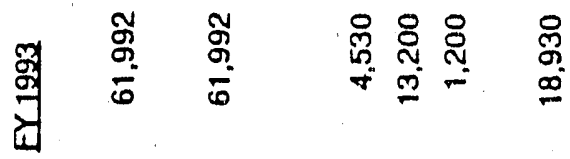

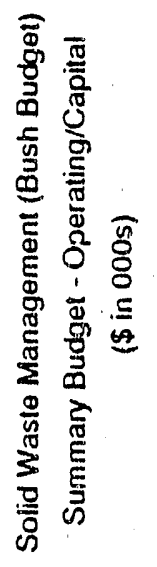

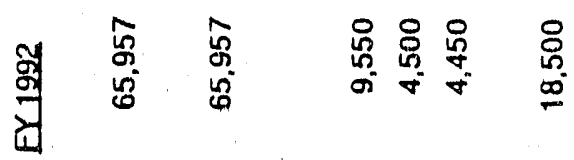

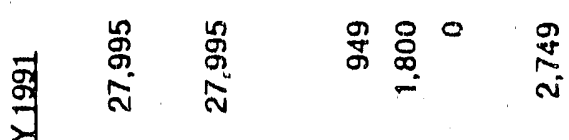

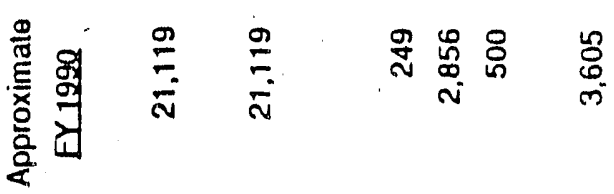

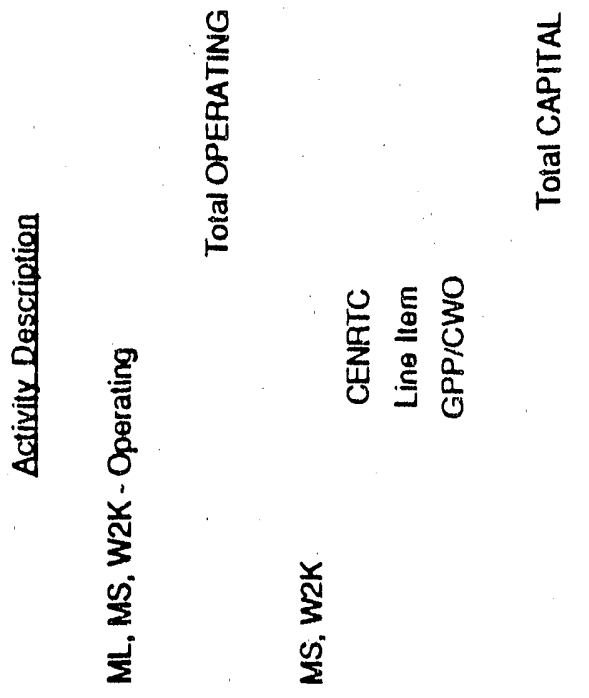




\subsection{REFERENCES}

AEC, 1970, Immediate Action Directive 0511-21, U.S. Atomic Energy Commission, Washington, D.C.

DOE-RL, 1990, 616 Nonradioactive Dangerous Waste Storage Facility, DOE/RL-89-03 (Rev 1), U.S. Department of Energy-Richland Operations Office, Richland, Washington.

Ecology, EPA, and DOE, 1989, Hanford Federal Facility Agreement and Consent Order, Washington (State) Department of Ecology, U.S. Environmental Protection Agency, and U.S. Department of Energy, Olympia, Washington.

Stickney, R.G., 1989, Hanford Site Radioactive Solid Waste Acceptance Criteria, WHC-EP-0063-1, Westinghouse Hanford Company, Rich1and, Washington.

Tank Farm Administration Support, 1989, Tank Farms and Solid Waste Management Administration Manual, WHC-CM-5-7, Westinghouse Hanford Company, Richland, Washington.

WHC, 1990, Hanford Site Waste Management Environmental Restoration Integration Plan, WHC-EP-0348, Westinghouse Hanford Company, Richland, Washington.

WHC, 1990, Hanford Site Environmental Restoration and Waste Management Technology Plan; WHC-EP-0212-1, Westinghouse Hanford Company, Richland, Washington.

WHC, 1988, Quality Assurance Manual, WHC-CM-4-2, Release 28, Westinghouse Hanford Company, Richland, Washington. 
WHC-EP-0363

APPENDIX A

DOCUMENT BASELINE

A-1/2 
WHC-EP-0363

\section{APPENDIX A \\ DOCUMENT BASELINE}

DOE Order 5820.2A (Radioactive Waste Management)

Establishes the policies, guidelines, and minimum requitements by which the DOE will manage the radioactive components of its. TRU, LLW, or HLWs. This order requires implementation plans for the management of such wastes. If any wastes contain hazardous components, the waste is to be managed in accordance with the RCRA as we11.

DOE Order 6430.1A (General Design Criteria)

Promotes general design criteria for use in the acquisition of DOE facilities and establishes responsibilities and authortties for the development and maintenance of these criterta. For waste management, the process systems are to minimize the production of wastes at the sources and minimize the mixing of radioactive and nonradioactive HWs. The waste mariagement systems are to provide facilities and equipment to handle wastes safely and effectively. Volume reduction equipment for both liquid and solid wastes are to be considered and designed for process capability and capacity commensurate with the types and quantities of wastes expected.

DOE Order 5480.1B (Environment, Safety, and Health Program for DOE Operations)

Establishes the program for operations of the DOE and its contractors with respect to protection of the public and the environment against radiation. Standards have been developed to protect aquifers and natural waterways against avoidable contamination by radioactive materials and to provide criteria for limiting radioactive doses to aquatic organisms.

\section{National Environmental Policy Act}

Establishes the underlying Federal policy for the protection of environmental quality and created a framework for implementing that policy. The primary means by which NEPA functions is the requirement for formal assessmeni of impacts resulting from any Federally furded project prior to initiation. Any project judged to have the potential to cause significant impacts on the environment must have an environmental impact statement prepared. Other less-formal documents are prepared if an EIS is not required. During the development of NEPA documentation, there is a necessity to consider other legislation, such as the Endangered Species Act.

Environmental Restoration and Waste Management Five-Year Plan

In August 1989 the DOE-HQ issued the Environmental Restoration and Waste Management FYP. The plan and its supporting documentation forms the basis for a 11 plannirig and budget requests for waste management, environmental 
Figure 1. Hanford Site Document Hierarchy.

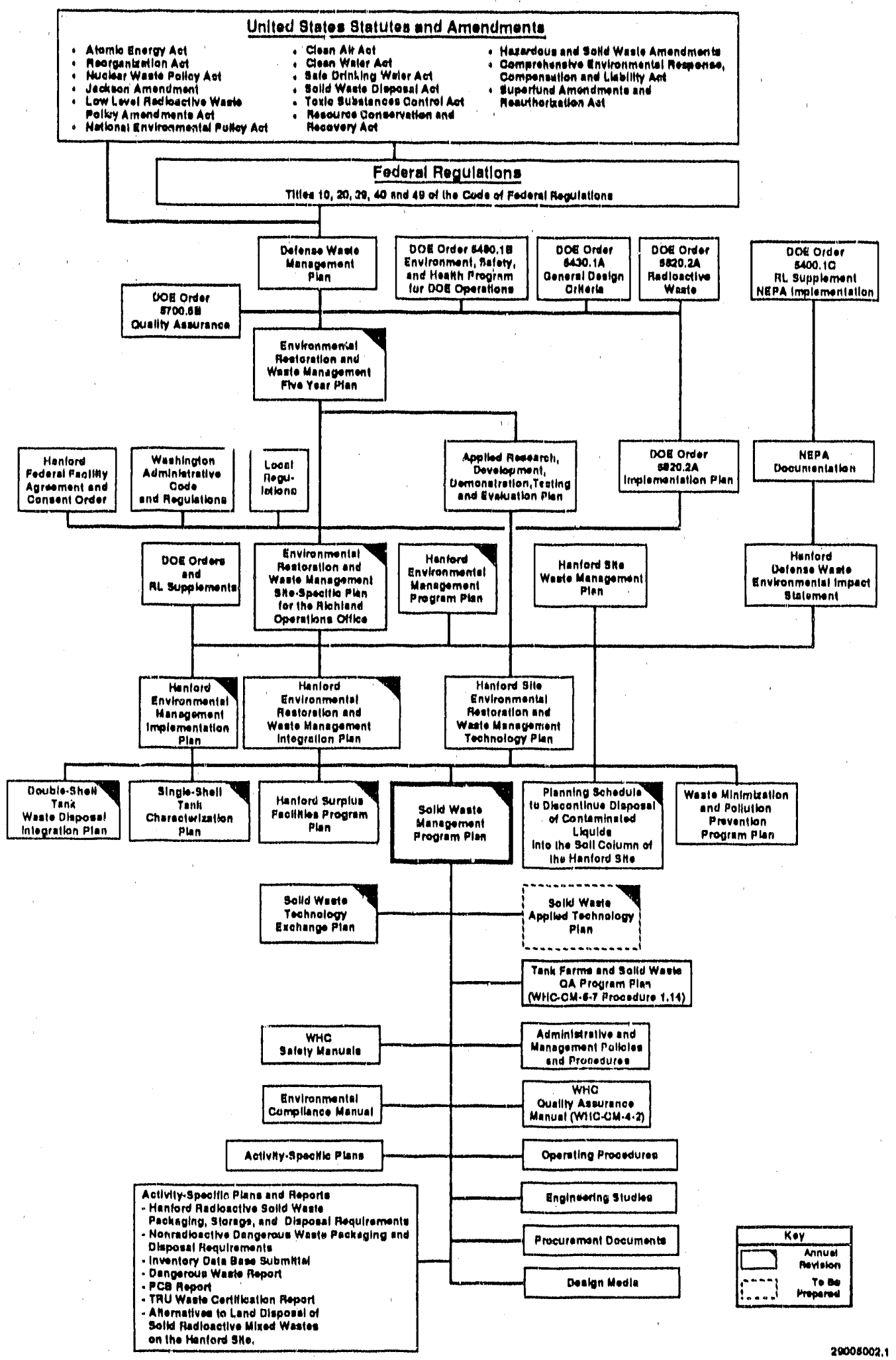


restoration, and environmental compliance activities throughout the DOE complex. The inftial FYP covered the FY 1991 through FY 1995. It constitutes the principal guiding document for the Waste Management Program, and hence SWM, at the Hanford Site. The next FYP, for FY 1992 through 1996, was issued in June 1990.

The FYP calls for each DOE field office to prepare activity data sheets and site-specific FYPs on an annual cycle as a basis for budget requests and to describe implementation of the FYP.

\section{Resource Conservation and Recovery Act}

Established the standards and requirements on a national basts for generation, TSD of HWs. The regulations require cradle-to-grave management of wastes, including minimization of generation. The regulations al so requiro permit applications for waste facilities describing destgn, operation, and closure parameters plans.

\section{Washington Dangerous Waste Regulations}

Ecology has the authority over a11 parts of the RCRA HW management program, except regulations promulgated under the Hazardous and Solid Waste Amendments to RCRA. The Washington Dangerous Waste Regulations are codifted in WAC 173-303.

\section{Site-Specific Plan (DOE-RL 89-25, DOE-RL 89-10, DOE-RL 89-17)}

Represents the principal budget and scope document for all of Hanford waste management and environmental restoration activities, responding to the DOE-HQ FYP. The SSP will be issued each fiscal year. Schedules and costs are discussed for each year by "activity data sheets" for major activities within environmental restoration and waste management. Total costs are given by year and activity data sheet for a 6 -yr period beyond the current fiscal year.

The SSP is prepared in three separate volumes, an overview, a detafled description, and an activity data sheet volume. The intital issuance in FY 1989 was: (1) The Environmental Restoration and Waste Management Site Specific Plan for the Richland Operations Office: Philosophy and Overview, DOE-RL 89-25, (2) Environmental Restoration and Waste Management Site-Specific Plan for the Richland Operations Office: Detailed Information, DOE-RL 89-10, and (3) The Hanford Site Environmental Restoration and Waste Management Five-Year Plan Activity Data Sheets, DOE-RL 89-17.

The next issue of the SSP will consist of the updated activity data sheet volume with budget and task information until FY 1996; it was issued in July. The overview volume will not be updated but the detailed volume will be revised and issued in early FY 1991. 


\section{RL Supplement to $5820.2 \mathrm{~A}$}

Establishes polictes, guidelines, and minimum requirements specific to the Hanford Site for DOE-RL. management of radioactive, RMW, and contaminated factlities. The supplement provides clarlfication of DOE-HO Order $5820.2 \mathrm{~A}$ and applicability of Washingtion State requirements to the Hanford Site.

\section{Implementation Plan for Hanford Site Compliance with 5820.2A (DOE-RL 89-05)}

Describes activities, costs and completion dates to achieve compliance with requirements for the management of radioactive and MWs.

Hanford Site Waste Management Plan (DOE-RL 89-32)

Overview of waste mariagement program at the Hanford Site, not including environmental restoration activities. The plan is an annual report describing how waste management operations are conducted, what factlities are being used to manage the wastes, and the plans for the current fiscal year. A summary budget and schedule is given for a 5-yr span.

\section{Hanford Stte Waste Management and Environmental Restoration Integration} Plan (WHC-EP-0348)

This plan discusses both waste management and environmental restoration activities unt 11 FY 2020 at the Hanford Site. The activities are structured into seven missions: DST wastes, SST wastes, encapsulated cesium and strontium wastes, solid wastes, liquid effluents, past practice units, and surplus facilities. The latter two missions are environmental restoration and the remainder are waste management. The SST mission is split, however. Surveillance and stabilization activities are waste marlagement while characterization and assessment are environmental restoration. Budgets are presented by fiscal year until 1996.

\section{Hanford Site Environmental Restoration and Waste Manaciment Technology Plan (WHC-EP-0212-1)}

Addresses the development and application of technology required for waste management and environmental restoration work at the Hanford Site. The technology needs are grouped by missions similarly to the Integration Plan, and discussed by major issues and subsidiary tasks. Costs and schedule are given in summary fashion for each mission for $25 \mathrm{yr}$ and totals are provided for each issue and task until completion.

Hanford Defense Waste Environmental Impact Statement (DOE/EIS-0113).

The HDW-EIS was developed to provide environmental input into the selection and implementation of final disposal actions for HLW, TRU wastes, and tank wastes located at the Hanford Site. An evaluation was also presented 
to assist in determining whether or not any additional action should be taken in terms of long-term environmental protection for waste that was disposed of at the Hanford site prtor to 1970 (before the TRU category was established).

The HDW-EIS ROD declares that retrievably stored and future TRU wastes are to be stored until disposed in the WIPP repository. The TRU waste from the pre-1970 burled suspect TRU contaminated solid waste (618-11 burial ground) site will also be retrieved and shipped to WIPP. Double-shell tank waste high-level fractions will be treated by vitrification and shipped to a geologic repository; low-level fractions will be treated by grouting in cement vauits. Encapsulated cesium and strontium wastes wili continue to be stored until shipment to a geologic repository. The decisions on the final disposal of all other wastes are deferred unt 11 additional development and evaluation are completed. In the interim, the Hanford Site will continue sturage and maintenance 'of the pre-1970 burted TRU solid waste sites. 
WHC-EP-0363

APPENDIX B

FACILITIES

$B-1 / 2$ 


\section{APPENDIX B}

FACILITIES

In order to present a complete picture of Solid Waste work, the facilities operated by the SWM function are described in this section. The section are divided into currently operating facilities and those planned or needed in the future. Photographs or conceptual drawings are provided where available.

\section{CURRENT FACILITIES}

The following facilities are operated by or uncier the control of SWM. Each facility is described by building number, facility description, and physical location.

272-WA Operations Support Building--This butlding houses the administrative support for the HCWC and is located in the 200 West Area.

213-W Compactor Facility--This facility, 10cated in the 200 West Area, houses a small LLW compactor that will compact the CH L.LW that is generated onsite into disposal boxes.

Hanford Central Waste Complex--The following buildings are used to store RMW in the HCWC located in the 200 West Area of the Hanford Site.

- 2401-W PCB/RMW Storage Facility

- 2402-W

- $2402-W B$

- 2402-WC

- 2402-WD

- 2402-WE

- $2402-W F$

- 2402-WG

- 2402-WH

- 2402-WI

- 2402-WJ

- 2402-WK

- 2402-WL.

616 Facility--This facility provides the final certification and shipping location for HWs that are sent to offsite TSD factlities.

340 Building--This facility, located in the 300 Area, is used for the shipment by railcar of liquid radioactive and RMWs from the 300 Area to the DSTs in the 200 Area. This facility does not handle physically solid waste but is controlled by the SWM Function due to its general role of managing offsite and intrasite waste receipts.

224-T TRUSAF-- The TRUSAF is used to store TRU waste certified for transfer to WIPP and is located in the 200 West Area. 
T Plant--This facility is used to decontaminate large equipment pieces prior to burial or reuse and is located in the 200 West Area.

Burial Grounds and Retrievable Storage Units--The burial grounds are located in 200 West and 200 East and are used for the disposal of lowTevel and $L L$ RH radioactive waste and the retrievable storage of $C H$ and RH TRU waste. Another burial ground in the 600 Area contains RH TRU waste to be retrieved.

- 218-E-12B is used for the disposal of naval reactor components and contains retrievably stored TRU waste.

- 218-E-10 is used for drag-off wastes from 200 East Area generators.

- 218-W-3A, 218-W-4B, 218-W-4C are used for the disposal of CH LLWS and contain retrievably stored TRU waste.

- 218-W-4B was used for storage of RH TRU waste in underground caissons.

- 218-W-3E is used for drag-off wastes from 100 Area and 200 West Area generators.

- 618-11 was used for storage of RH TRU waste in underground caissons.

3718 Alkali Metal Treatment and Storage Facility--Sodium and NaK was stored in the $3718 \mathrm{~F}$ Building. No material is currently stored in this building, and its future usage is being evaluated.

4843 Alkali Metal Storage Facility--This facility is used for alkali metal storage.

27275--This facility was used to store nonradioactive waste from 1983 to 1986 , when all stored waste was removed. The building will be transferred to Environmental Restoration when the closure plan has final approval.

E-8 Borrow Pit Demolition Site--This facility was used for demolition of explosive wastes. Solid Waste Management is responsible for the closure plan preparation.

Ashpit Demolition Site--This facility was used for demolition of explosive wastes. Solid Waste Management is responsible for the closure plan preparation.

Hanford Patrol Academy Demolition Site--This site will continue to be used for demolition of explosives. Solid Waste Management is responsible for the Part B Permit preparation.

2727W and 2727WA Facilities--These facilities will store and distribute sodium hydroxide for use in the PUREX facility. 


\section{FUTURE FACILITIES}

The following facilities will be under the control of SWM in the near future. Each facility is described by planned operational date, building number, facility description, capacity (if any), and physical location.

WRAP Module I--WRAP Module I is planned to be operational by FY 1996. It will have the capability to certify retrieved and newly generated drummed $\mathrm{CH}$ TRU and LLW. The facility will include a nondestructive assay (NDA)/nondestructive examination (NDE) area which will determine if suspect TRU waste meets the criteria of LLW or TRU. There will be an open sort area where non-compliant items which will not meet the WIPP acceptance criteria can be removed. Module I will be configured to allow loading of CH TRU into TRUPACT-II shipping containers. Module I will be able to certify newly generated smal1 boxes of TRU, but will not handle large boxes of retrieved waste. The assay capabilities of Module I will replace those currently in the TRUSAF Facility.

Moderate Hazard Storage Facility--This facility is planned to be operational concurrent with WRAP Module I and will provide lag storage for $\mathrm{CH}$ TRU waste awaiting characterization data prior to processing in WRAP, provide storage for waste removed from temporary suspect

TRU storage areas until it can be processed in WRAP, provide shipping and receiving operations for TRUPACT-II shipments to WIPP, provide shipping and receiving operations for onsite shipments of other wastes being processed in WRAP or being stored in the MHSF, provide storage for RH waste awaiting processing in WRAP Module II, and provide longterm storage for wastes classified as LL-GTCH. Alternatively, GTCH may be stored in a separate facility.

WRAP Moduie II--WRAP Module II is planned to be operational by FY 1999 and will perform the main TSD functions for a wide range of solid wastes at the Hanford Site. The WRAP Module II will process retrieved suspect TRU boxes, resins, and ion exchange materials; neutralization of materials; oxidation of materials; treatment of LLW, LLW/MW, and uncertifiable TRU material; NDE/NDA of $\mathrm{CH}$ boxes up to $4 \mathrm{ft}$ high by $5 \mathrm{ft}$ wide by $8 \mathrm{ft}$ long; preparation of RH materials; and decontamination of lead, miscellaneous equipment pieces, and vehicles used to deliver waste packages.

618-11 Retrieval Facility--This facility will recover wastes disposed of in the 618-11 burial ground, package the wastes in drums and boxes, and send the waste to WRAP for final certification and shipment to WIPP.

Alpha Caissons Retrieval Facility--This facility will recover wastes disposed in the Alpha Caissons in the 200 Area, package the wastes in drums and boxes, and send the waste to WRAP Module II for final certification and shipment to WIPP.

Large Mixed Waste Storage Facility, Phase I - IV--The large Mixed Waste Storage Facility (Phases I through IV) will provide more RMW storage canacity in the HCwC prior to treatment and final disposal. 
Radioactive Mixed Waste Disposal Facility--This trench facility (Project $W-025)$ is planned to be a permanent RCRA-compliant disposal facility that will accept all classes of CH LLW and LLW/MW other than GTCH. A special section may al so accept $R H$ waste in the above classifications.

Retrievably Stored TRU Retrieval Facilities--The retrieval facilities will exhume the drums and boxes from storage; package them for shipment; provide an approximation of fissile contents via fixed or portable assay equipment; bar code identify the package; provide manifests for the packages; and vent containers, sample head gasses, and install filters. 
Figure B-1. Hanford Central Waste Complex, 200 West Area.

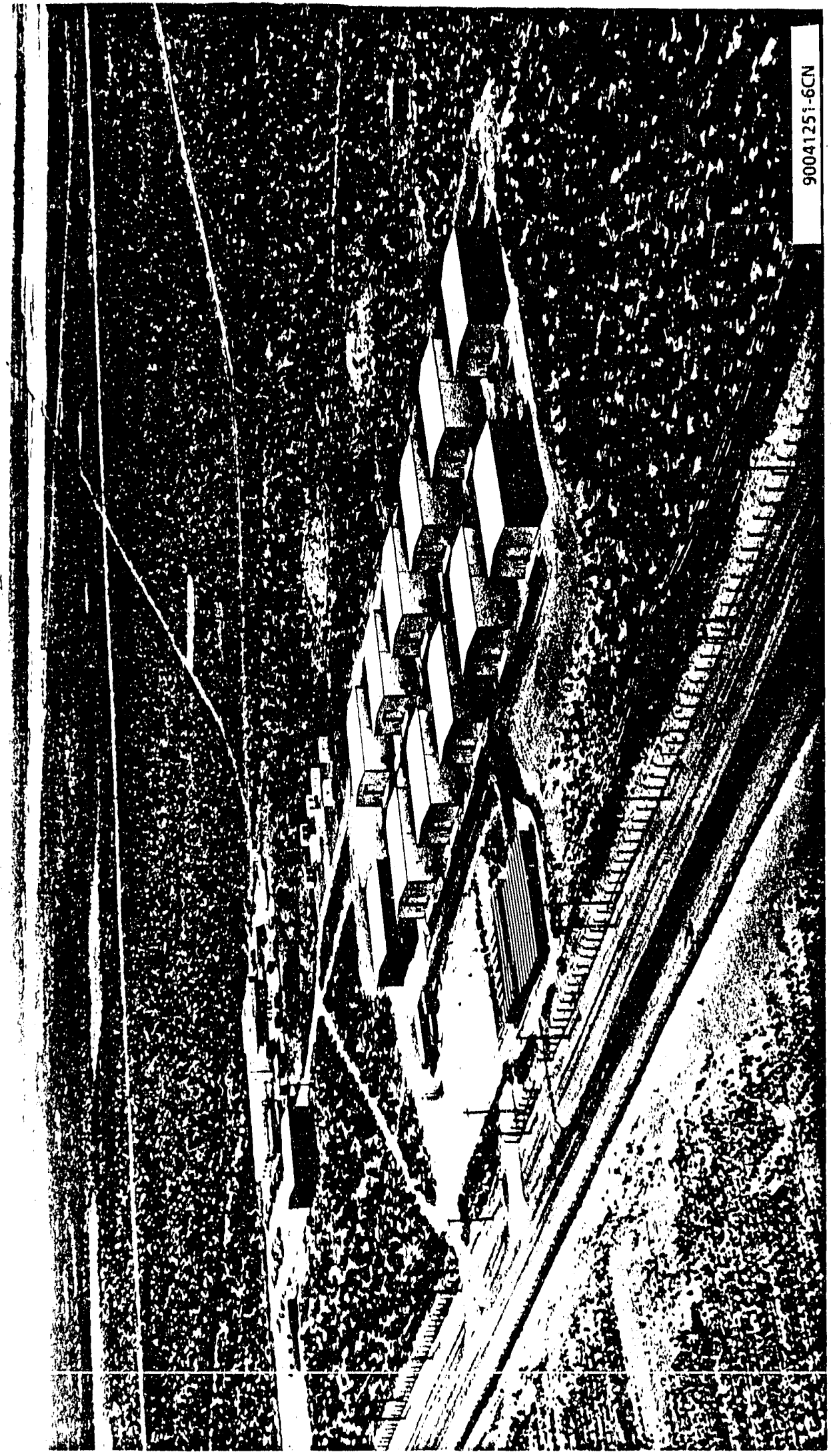

$B-7 / 8$ 
WHC-EP-0363

Figure B-2.

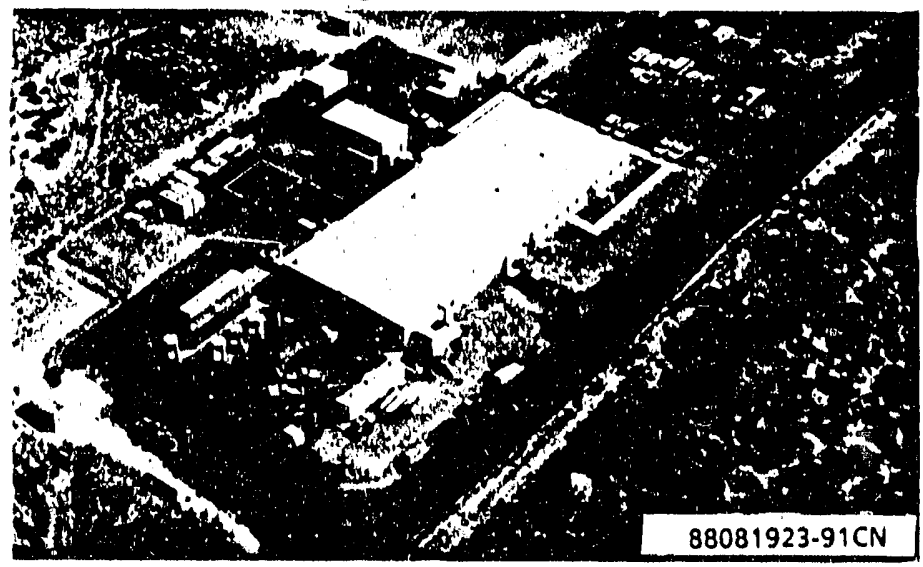

272-WA Operations Support Building for the Hanford Central Waste Complex.

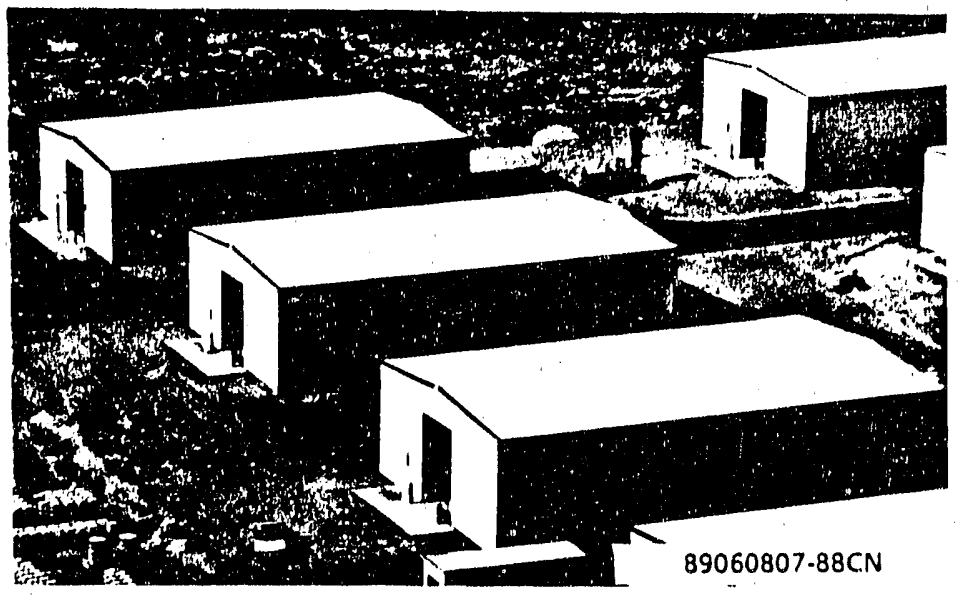

Typical Mixed Waste Storage Buildings at the Hanford Central Waste Complex.

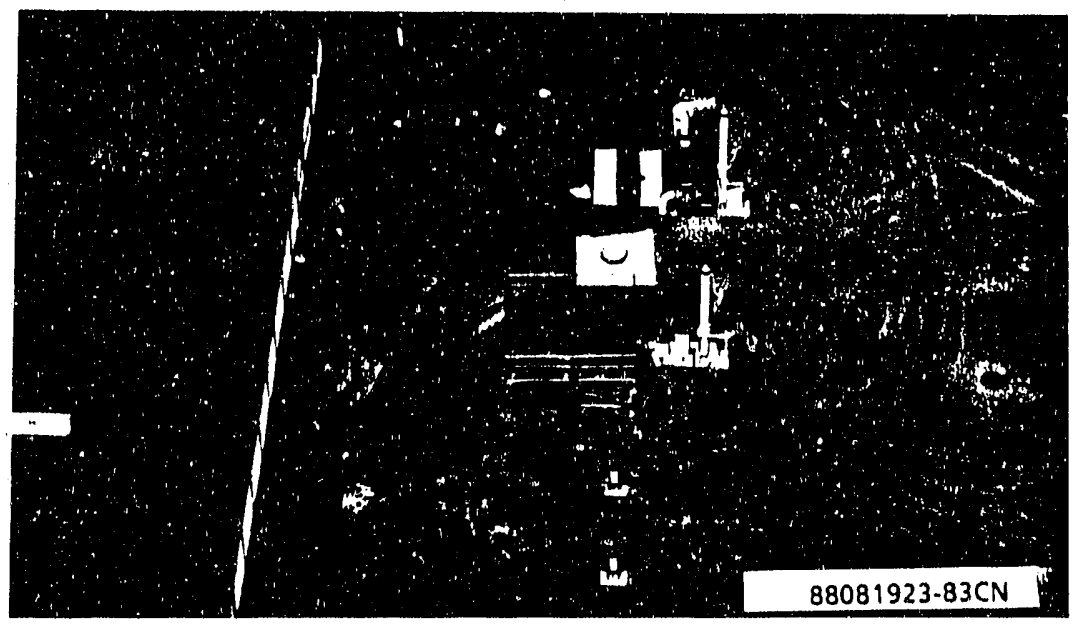

Alpha caissons, 200 West Area.

$$
8-9 / 10
$$


Figure B-3. TRU Retrievable Storage Burial Ground 4C 200 West Area.

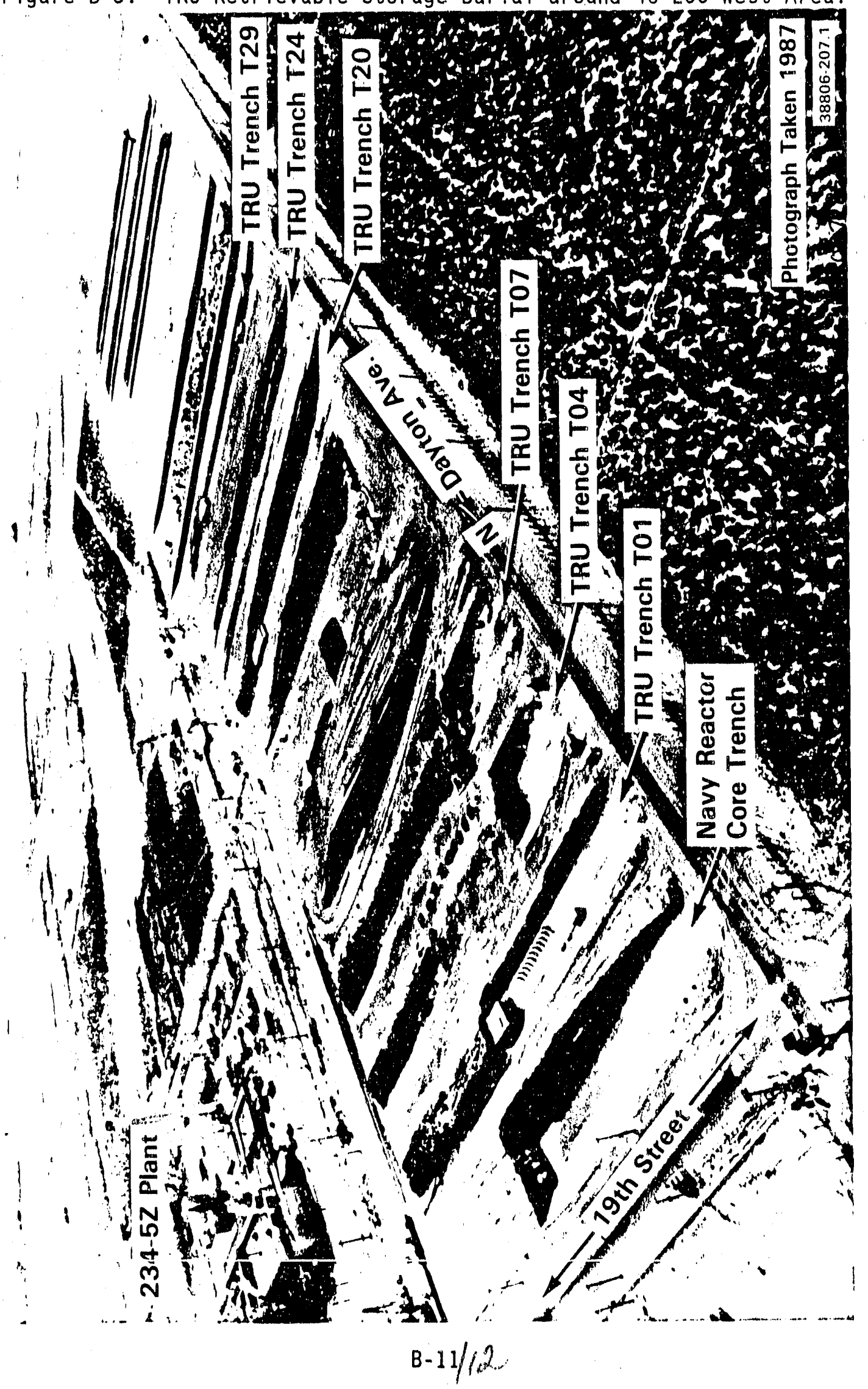


Figure B-4. 213-W Waste Compactor, 200 West Area.

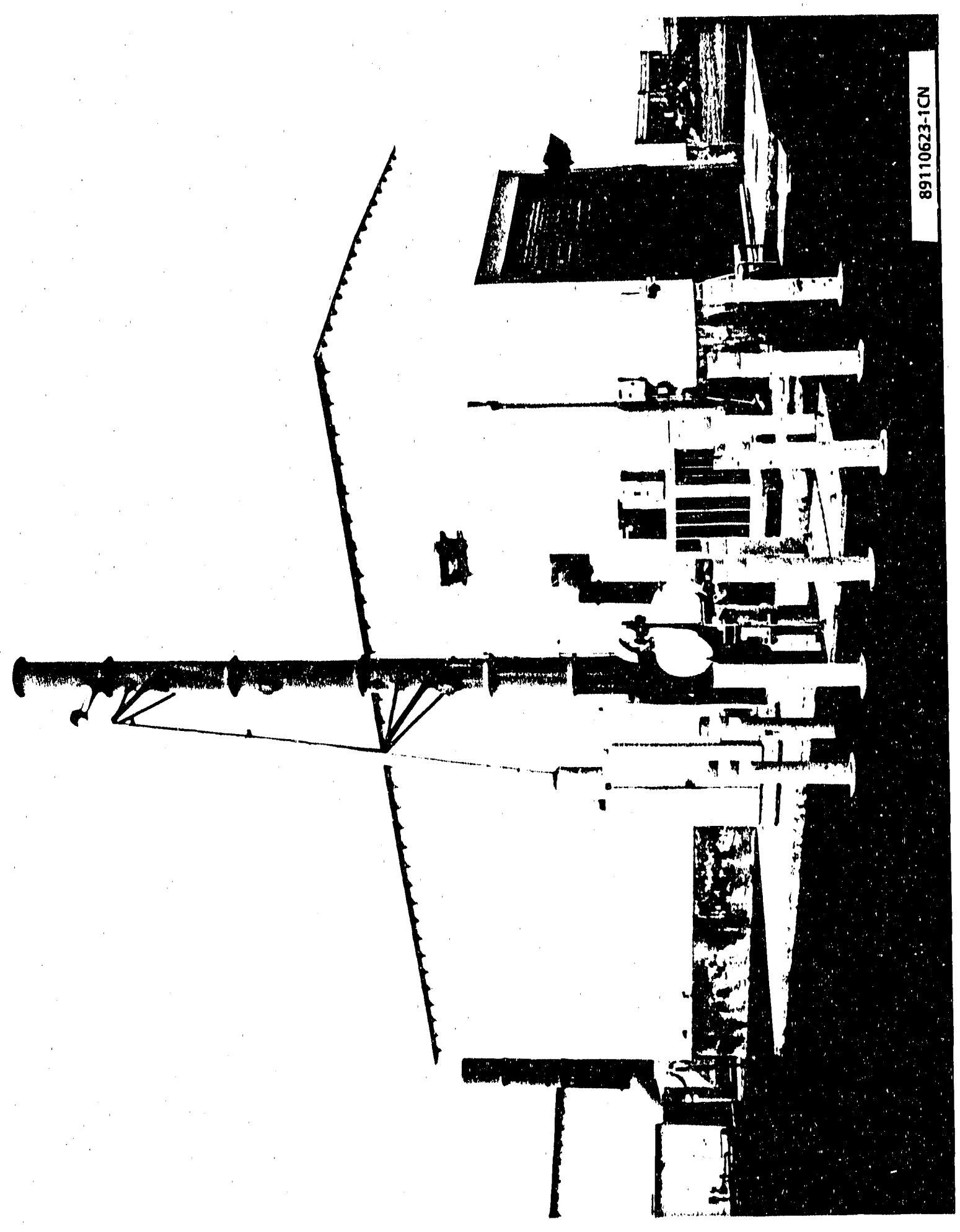


Figure B-5. Transuranic Storage and Assay (TRUSAF) Facility, 224-T-200 West.

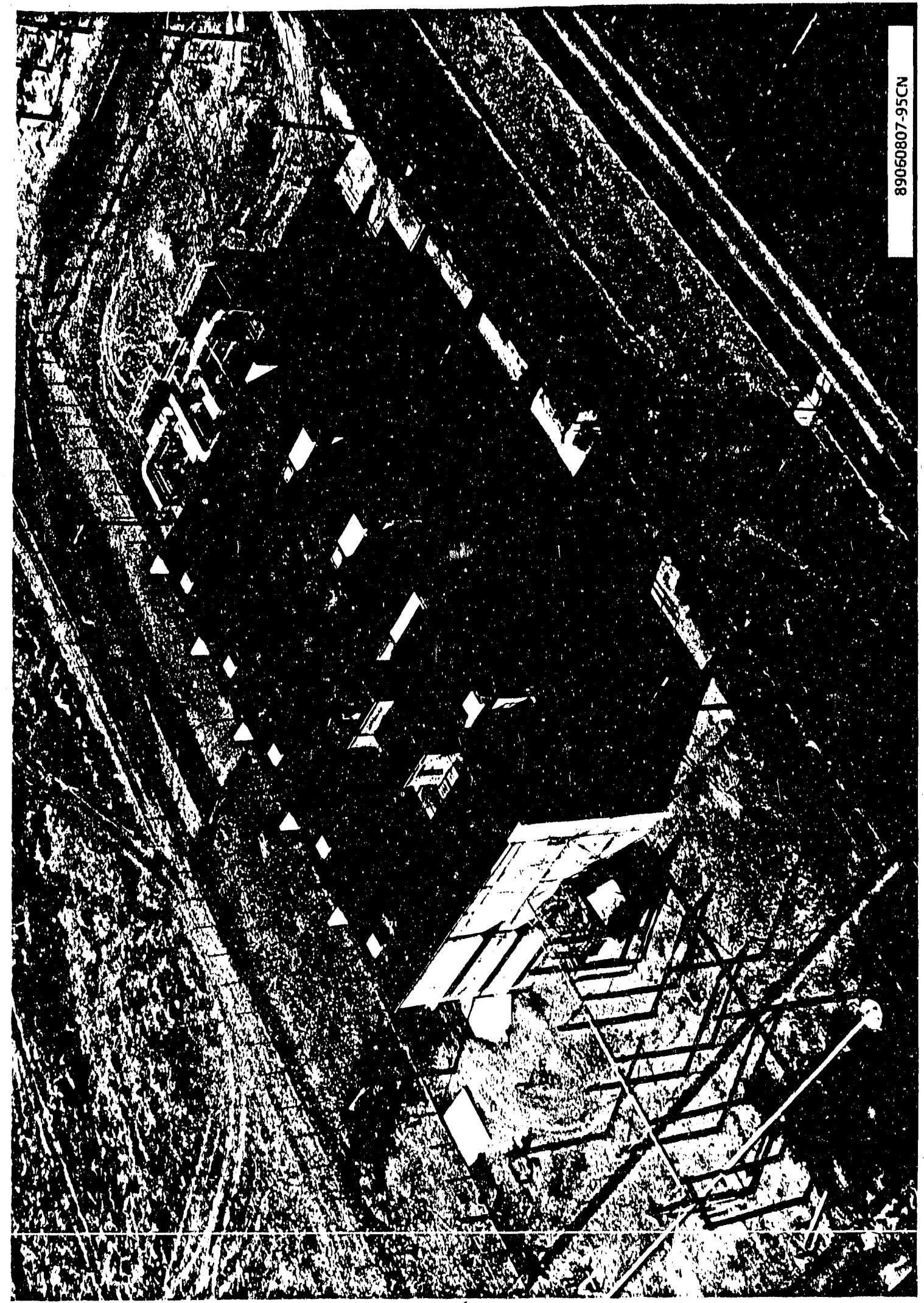

$$
B-15 / 16
$$


WHC-EP-0363

Figure B-6. 616 Butlding.

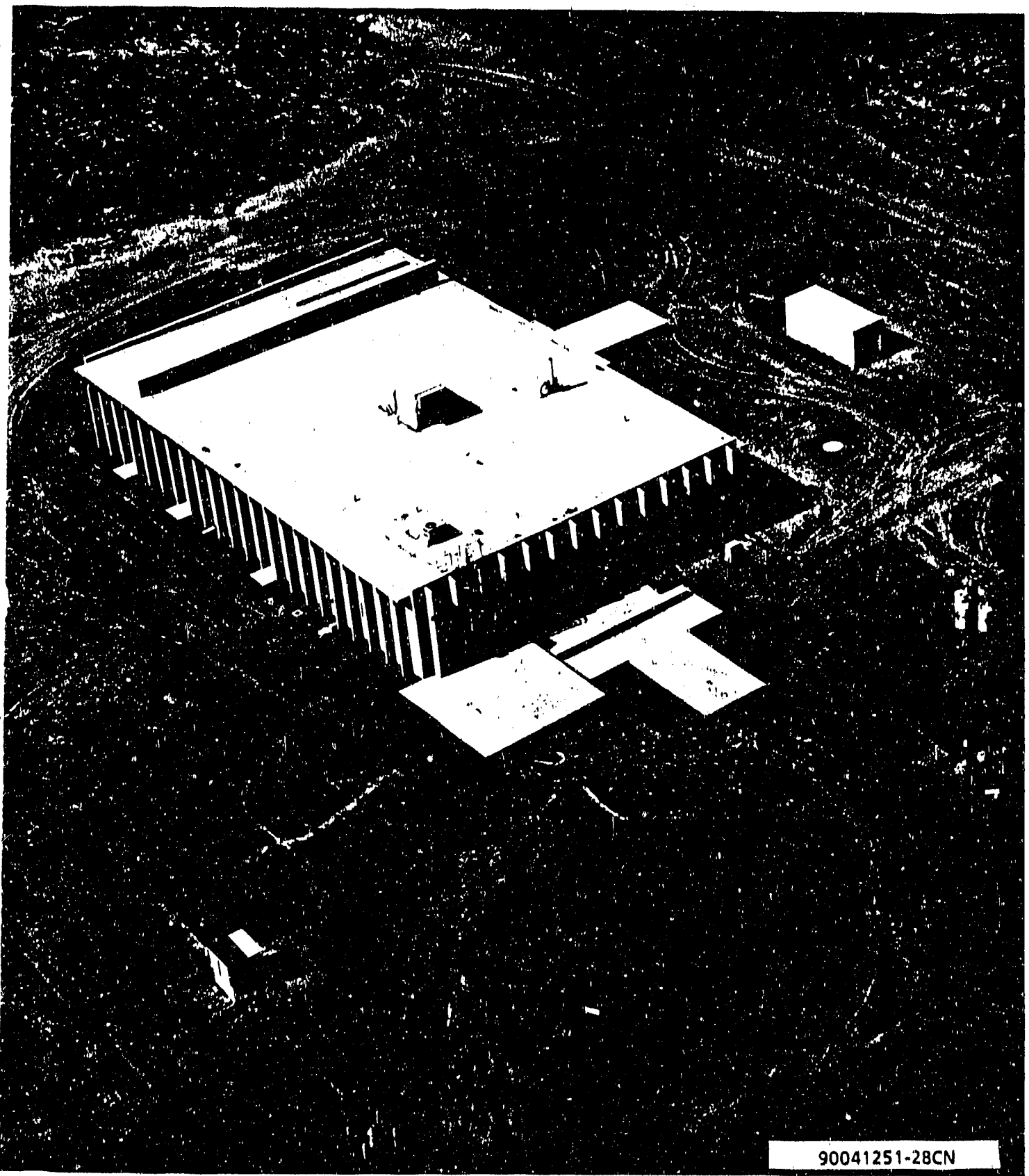


WHC-EP-0363

Figure B-7. 2727-S Dangerous Waste Storage Factlity.

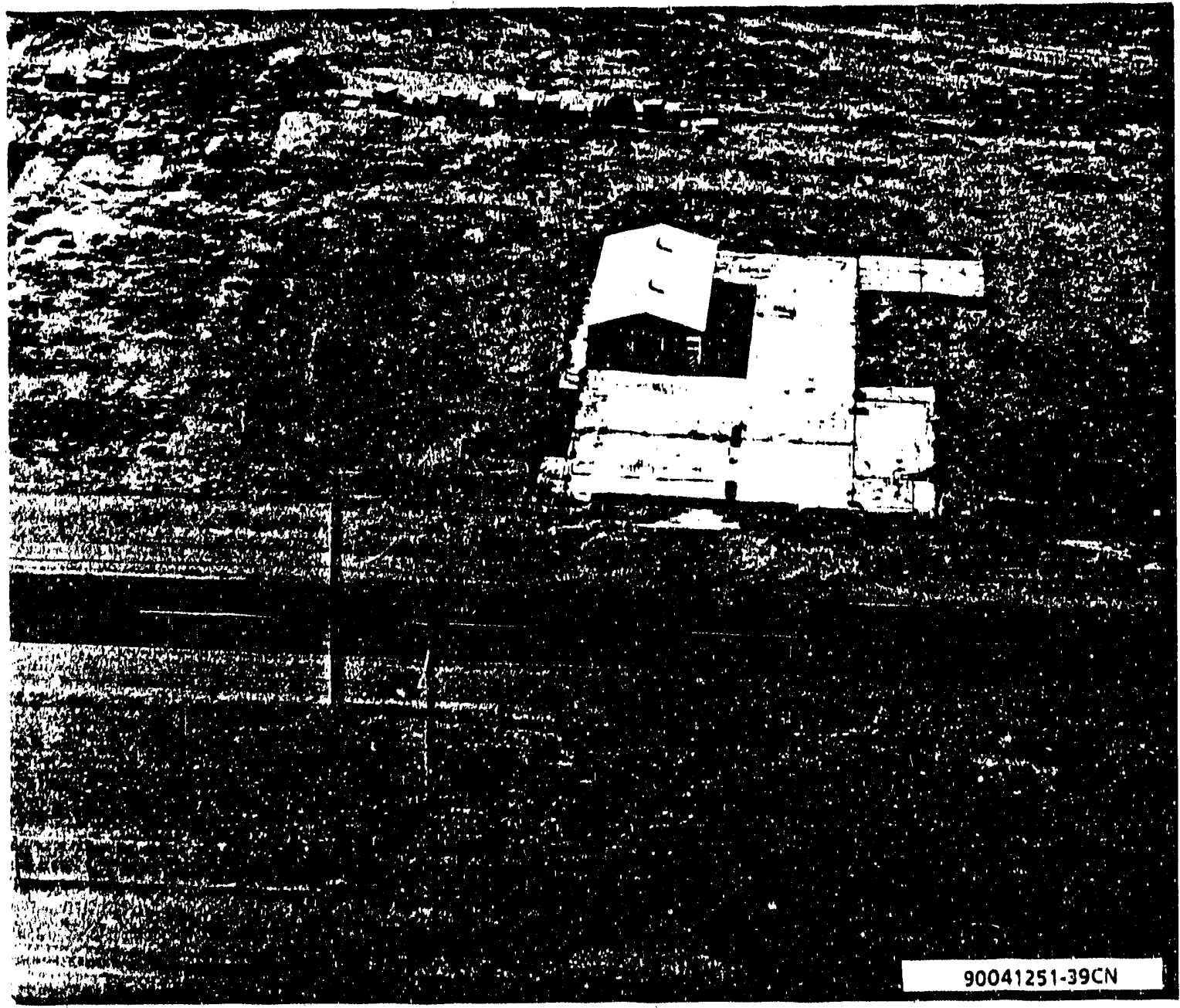


Figure B-8. Conceptual Drawing of the Waste Recelving and Processing Facillty (WRAP) Module 1.

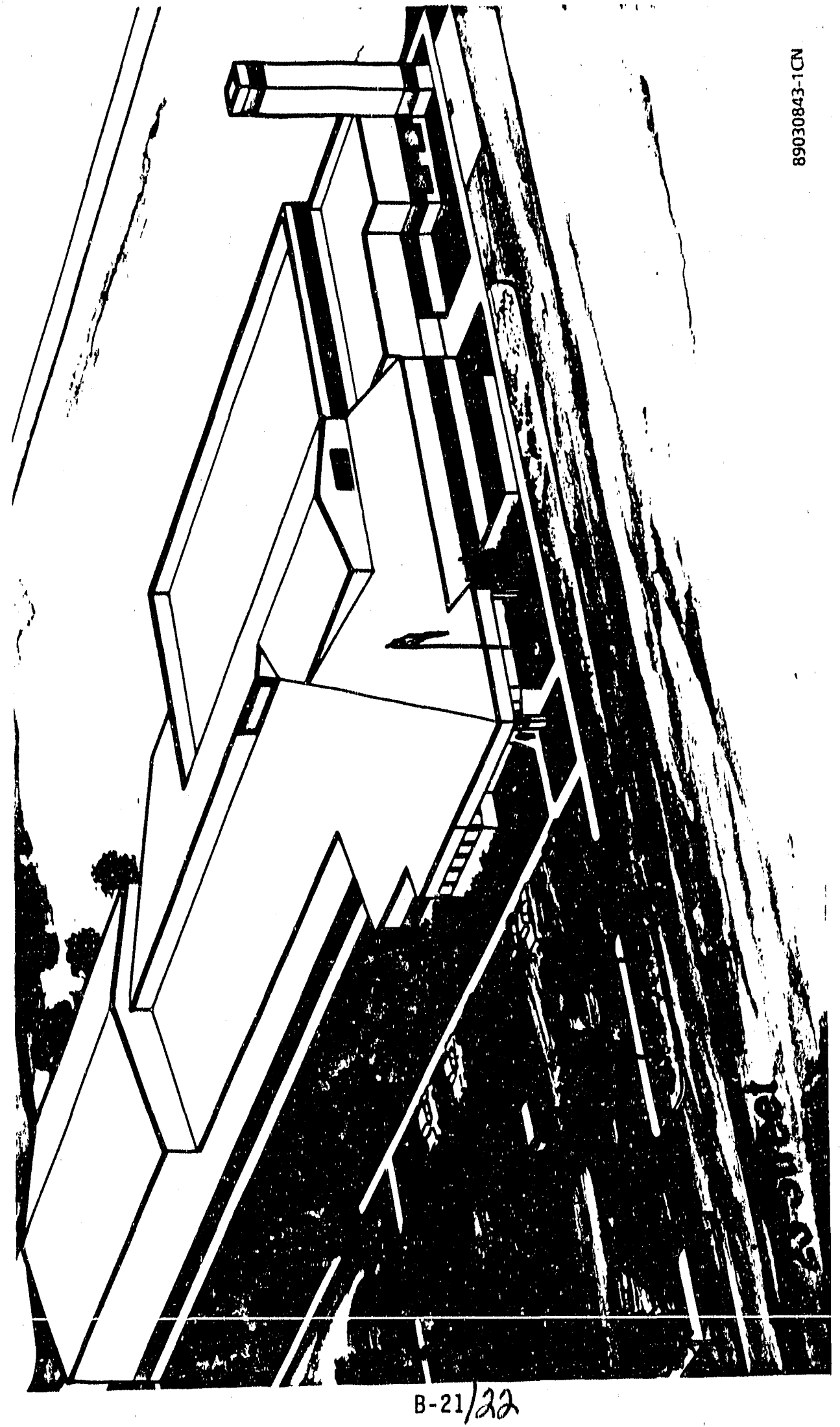



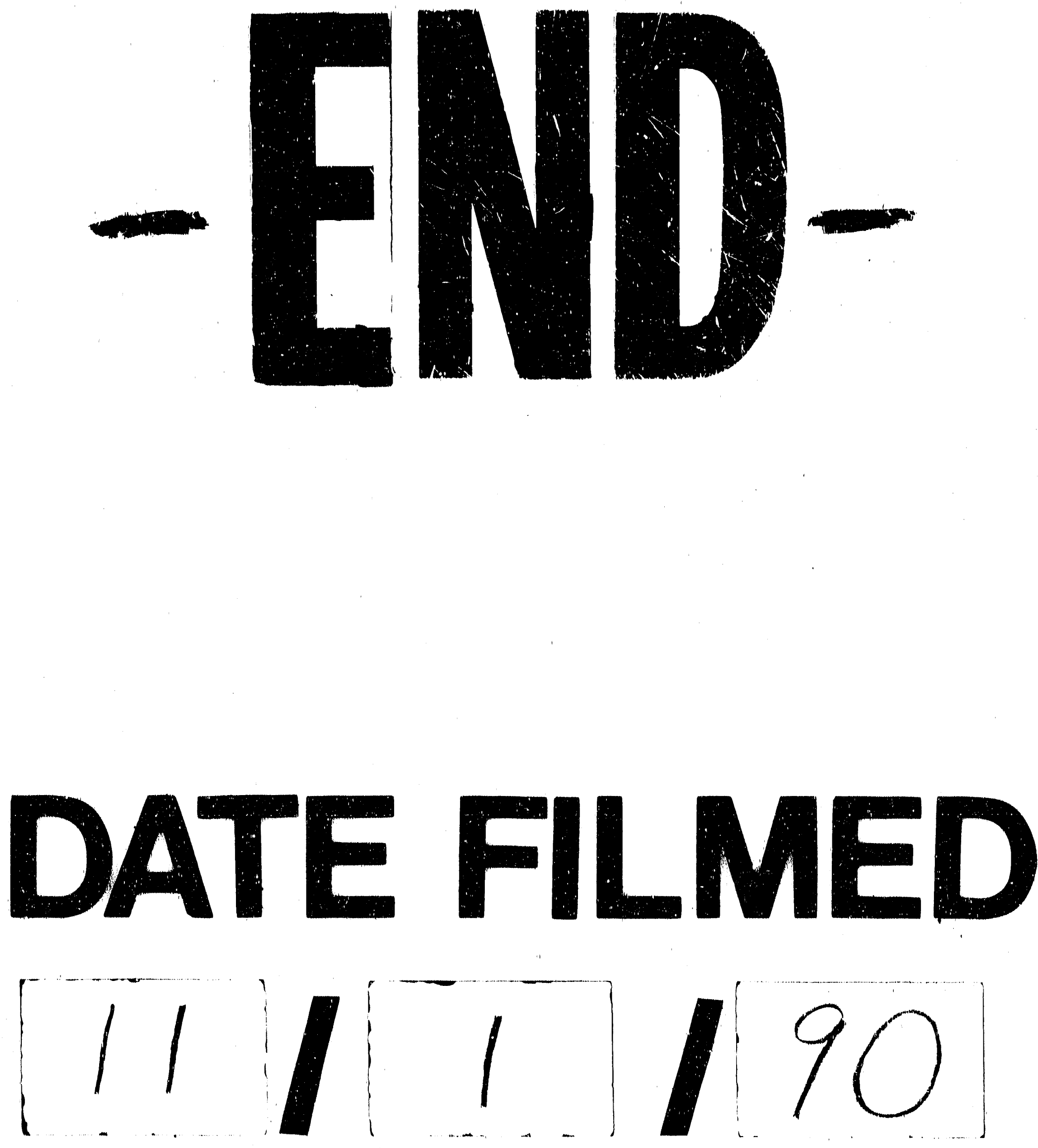
! 